\section{Radboud University Nijmegen}

\author{
P.O. Box 9102, NLD 6500 HC Nijmegen, Netherlands
}

Tel: $\quad$ (31) 243616161

Fax: (31) 243564606

Website: www.ru.nl/english

Radboud University is a student-oriented research university that aspires to be one of the best in Europe. The goal is for all research programmes to be rated 'very good' and for degree programmes to rank among the top $25 \%$ of Dutch universities.

\section{Radboud Scholarship Programme}

Purpose: The Radboud Scholarship Programme offers a select number of talented prospective non-EEA students the opportunity to receive a scholarship to pursue a complete English-taught Master's degree programme at Radboud University

Eligibility: You will only be eligible to obtain a Radboud Scholarship if you: 1. hold a non-EU/EEA passport. 2. are not eligible for the lower EEA tuition fee for other reasons. 3. have (will obtain) a Bachelor's degree achieved outside the Netherlands, have no degrees achieved in the Netherlands and did not receive any previous education in the Netherlands. 4. have a high level of language proficiency. 5. have been fully admitted to the English-taught Master's degree programme starting 01 September as stated in the formal letter of admission. 6. are able to comply with the conditions for obtaining a visa for the Netherlands

Level of Study: Graduate

Type: Scholarship

Frequency: Annual

Country of Study: Any country
Application Procedure: From the eligible candidates the Radboud Scholarship holders will be selected based on the following criteria: 1 . Talent: this means that you must have outstanding study results in your present field of study. 2 . You are expected to be a promising student in your desired field of study at Radboud University. 3. Proven academic quality and good results of your prior education for example through grades, test scores, publications. 4. Quality of the recommendations in the two reference letters. 5. Motivation: based on your motivation letter for the Master's progamme

Closing Date: 1 March

Funding: Private

\section{For further information contact:}

Radboud University Houtlaan 4, NLD 6525 XZ Nijmegen, The Netherlands

Email: rsp@io.ru.nl

\section{Radboud Scholarships Programme for Masters Students}

Purpose: The Radboud Scholarship Programme offers a select number of talented prospective non-EEA students the opportunity to receive a scholarship to pursue a complete English-taught Master's degree programme at Radboud University Nijmegen

Eligibility: Applicants will be eligible to obtain a Radboud Scholarship if they hold a non-EU/EEA passport; are not eligible for the lower EEA tuition fee for other reasons; have been fully admitted to the English-taught Master's degree programme as stated in the formal letter of admission; are able to comply with the conditions for obtaining a visa for the Netherlands; are enroled at Radboud University as a fulltime student for the academic year and Master's degree programme for which the scholarship will be awarded Level of Study: Graduate 
Type: Scholarship

Value: The scholarship consists of a partial tuition waiver. The tuition fee will be waived to the level of an EEA student. In addition the Radboud Scholarship also covers costs such as those for visa, residence permit, health insurance and liability insurance. This amounts to about $€ 700$. For detailed information, please visit www.ru.nl/english/education/master'sprogrammes/financial-matters/scholarships-grants/read_more/ rsprogramme/

Country of Study: Netherlands

Application Procedure: The application for admission and the application for the scholarship is fully integrated, there is no separate procedure for the scholarship. Applicants must apply for a Radboud Scholarship by indicating during their application for admission that they wish to apply for a Radboud Scholarship. Applicants will then be requested to upload three additional documents including two recommendation letters and a curriculum vitae. Applicants also must have finalized their request for admission before the deadline Closing Date: 1 April

Additional Information: For more information about the scholarship programme, contact the International Office on rsp@io.ru.nl

\section{For further information contact:}

Email: rsp@io.ru.nl

\section{Radcliffe Institute for Advanced Study}

Byerly Hall, 8 Garden Street, Cambridge, MA 02138, United States of America

$\begin{array}{ll}\text { Tel: } & \text { (1) } 6174958212 \\ \text { Fax: } & \text { (1) } 6174958136 \\ \text { Email: } & \text { alison_ney@radcliffe.harvard.edu } \\ \text { Website: } & \text { www.radcliffe.edu } \\ \text { Contact: } & \text { Administrator of Fellowships }\end{array}$

The Radcliffe Institute for Advanced Study is a scholarly community where individuals pursue advanced work across a wide range of academic disciplines, professions and creative arts. Within this broad purpose, the Radcliffe Institute sustains a continuing commitment to the study of women, gender and society.

\section{Radcliffe Institute Fellowship}

Subjects: A range of disciplines across the humanities and social sciences, natural sciences and mathematics, and creative arts
Purpose: The Radcliffe Institute for Advanced Study at Harvard University awards 50 funded residential fellowships each year designed to support scholars, scientists, artists, and writers of exceptional promise and demonstrated accomplishment

Eligibility: For eligibility guidelines, please refer to our application portal

Level of Study: Postdoctorate

Type: Fellowship

Value: US $\$ 77,500$

Length of Study: September-May

Frequency: Annual

Country of Study: Any country

Application Procedure: Please refer to our webpage for more information: www.radcliffe.harvard.edu/fellowshipprogram/how-apply

Closing Date: 12 September

Funding: Private, Individuals

\section{For further information contact:}

Email: alison_ney@radcliffe.harvard.edu

\section{Radiological Society of North America, Inc. (RSNA)}

820 Jorie Boulevard, Oak Brook, IL 60523 2251, United States of America
Tel: $\quad$ (1) 6305712670
Fax: (1) 6305717837
Email: swalter@rsna.org
Website: www.rsna.org/foundation
Contact: $\quad$ Mr Scott Walter, Assistant Director, Grant
Administration

The Research and Education Foundation of the Radiological Society of North America (RSNA) provides grant support to medical students, residents, Fellows and full-time faculty members of departments of radiology, radiation oncology and nuclear medicine.

\section{Medical Student Research Grant}

Purpose: This R\&E Foundation grant gives medical students the opportunity to gain research experience in medical imaging while they're still in school. Recipients will define objectives, develop research skills and test hypotheses, 
Eligibility: 1. You must be an RSNA member to apply for the Medical Student Research Grant. If you're a non dues-paying member, your scientific advisor or your co-investigator must be a dues-paying member. You must also meet the following criteria. 2. You must be a full-time medical student at an accredited North American medical school. 3. You must commit to work full-time for at least 10 weeks on your research project. 4. Your research project must take place in a department of radiology, radiation oncology or nuclear medicine in a North American medical institution, but this doesn't have to be the same institution where you're enrolled as a student. 5. You cannot have been a principal investigator on a grant or contract totaling more than US\$60,000 in a single year. This includes single and combined grants and contracts from government, private and commercial sources. 6. You and your principal investigators cannot be employed by any for-profit, commercial company in the radiologic sciences. 7. You cannot submit more than one grant application to the RSNA R\&E Foundation a year, and cannot have a concurrent RSNA grant. 8. Funding from other grant sources must be approved by foundation staff if it wasn't described in the original research plan

Level of Study: Research

Type: Research grant

Frequency: Annual

Country of Study: Any country

Application Procedure: For detailed information, check the following link, ektron.rsna.org/uploadedFiles/RSNA/Con tent/R_and_E_Foundation/Grants_and_Awards/RMS_Poli ciesProcedures.pdf

Closing Date: 1 February

Funding: Private

\section{For further information contact:}

820 Jorie Blvd., Suite 200 Oak Brook, IL 60523-2251, United States of America

Email: rmurray@rsna.org

\section{Radiological Society of North America Education Seed Grant}

Subjects: Radiologic sciences

Purpose: To provide funding opportunities for individuals with an active interest in radiologic education

Eligibility: Applicants must hold a faculty position in a department of radiology, radiation oncology, or nuclear medicine within a North American, educational institution and must have completed advanced training and be certified by the American Board of Radiology (or equivalent), or on track for certification. Applicants must not have received grant/contract amounts totaling $\$ 50,000$ or more in a single calendar year as principal investigator

Level of Study: Research

Type: Grant

Value: Up to $\$ 30,000$ to support the preliminary or pilot phase of education projects, not to supplement major funding already secured. No salary support for the principal investigator will be provided

Frequency: Annual

Country of Study: Any country

Application Procedure: Application can be submitted online Closing Date: 10 January

Funding: Foundation

\section{For further information contact:}

Email: rmurray@rsna.org

\section{Radiological Society of North America Institutional Clinical Fellowship in Cardiovascular Imaging}

Subjects: Cardiovascular imaging

Purpose: To provide opportunities for radiologists early in their careers to gain experience and expertise in cardiovascular imaging

Eligibility: Open to citizens or permanent residents of a North American country who have completed their residency training in the radiological sciences. Fellows must also hold an MD or the equivalent as recognized by the American Medical Association and must be ACGME-certified in radiology or be eligible to sit for such certification

Type: Fellowship

Value: US\$50,000 per year paid to a department. The Foundation does not pay overhead or indirect costs

Length of Study: 3 years

Frequency: Annual

Country of Study: Any country

Application Procedure: Applications must be submitted by a department in preparation for the recruitment of a Fellow into an existing cardiovascular imaging training programme. Application forms are available from the website

Closing Date: 1 June

For further information contact:

Email: bcartalino@rsna.org

\section{Radiological Society of North America Medical Student Grant Program}

Subjects: Radiology and related disciplines 
Purpose: To make radiology research opportunities available for medical students early in their training and encourage them to consider academic radiology as a career option

Eligibility: Open to full-time medical students at an accredited North American medical school

Level of Study: Research

Type: Grant

Value: US $\$ 3,000$ for an 10 -week (minimum) research project, to be matched by the sponsoring department (US\$6,000 total), as a stipend for the medical student

Length of Study: 1 year

Frequency: Annual

Country of Study: Any country

Application Procedure: Applicants must complete an application form available from the website rsna.org/foundation

Closing Date: 1 February

Funding: Foundation

Contributor: Individuals, private practice, corporate

For further information contact:

Email: bcartalino@rsna.org

\section{Radiological Society of North America Research Resident Program}

Subjects: Radiology, radiation oncology and nuclear medicine

Purpose: To provide opportunities for individuals to gain further insight into scientific investigation, and to develop competence in research and educational techniques and methods

Eligibility: Open to citizens or permanent residents of a North American country. Applicants should be in residency training so that the award can occur during any year after the 1st year of training and should have an academic degree acceptable for a radiology residency

Level of Study: Postgraduate

Type: Grant

Value: US $\$ 30,000$ designed to replace a portion of the resident

Length of Study: 1 year, non-renewable

Frequency: Annual

Country of Study: Any country

Application Procedure: Applicants must complete an application form, available from the website

Closing Date: 15 January

\section{For further information contact:}

Email: bcartalino@rsna.org

\section{Radiological Society of North America Research Resident/Fellow Program}

Subjects: Radiology or related disciplines

Purpose: To provide young investigators not yet professionally established in the radiological sciences an opportunity to gain further insight into scientific investigation and to develop competence in research techniques and methods

Eligibility: Applicants must be a resident or fellow in a department of radiology, radiation oncology or nuclear medicine within a North American educational institutions at the time of application

Level of Study: Doctorate, Postdoctorate

Type: Fellowship

Value: US $\$ 30,000$ for a 1-year Research Resident project or US $\$ 50,000$ for a 1-year Research Fellow project, to be used for salary and/or non-personnel research expenses

Length of Study: 1 year

Frequency: Annual

Country of Study: Any country

Application Procedure: Applicants must complete an application form, available from the website rsna.org/ foundation

Closing Date: 15 January

Funding: Foundation

Contributor: Individuals, private practice, corporate

\section{For further information contact:}

Email: bcartalino@rsna.org

\section{Radiological Society of North America Research Scholar Grant Program}

Subjects: Medical sciences

Purpose: To support junior clinical faculty members and allow them to gain experience in research early in their academic careers

Eligibility: Applicants must be within 5 years of initial faculty appointment in a department of radiology, radiation oncology or nuclear medicine within a North American institution

Level of Study: Doctorate, Postdoctorate

Type: Award

Value: US $\$ 75,000$ per year for 2 years (US $\$ 150,000$ total), payable to the institution, to be used exclusively as a stipend for the scholar

Length of Study: 2 years

Frequency: Annual

Country of Study: Any country 
Application Procedure: Scholar applicants must be nominated by their host institution. Applicants must complete an application form available from the website rsna.org/ foundation

Closing Date: 15 January

Funding: Foundation

Contributor: Individuals, private practice, corporate

\section{For further information contact:}

Email: bcartalino@rsna.org

\section{Research Scholar Grant}

Purpose: This R\&E Foundation grant supports junior faculty members who have completed resident and fellowship programs, but haven't been recognized as independent investigators Eligibility: Any junior radiology faculty member may apply for the Research Scholar Grant, as long as you are an RSNA member and meet the following criteria: 1. You must hold a full-time faculty position in a department of radiology, radiation oncology or nuclear medicine within a North American educational institution. 2. You must have been hired within the last 5 years with an academic rank of instructor, assistant professor or an equivalent title. 3. You must have completed advanced training and be certified by either the American Board of Radiology (ABR), The Royal College of Physicians and Surgeons of Canada or are on track for certification. 4. You cannot have been a principal investigator on a grant or contract totaling more than US\$60,000 in a single year. This includes single and combined grants and contracts from government, private and commercial sources. 5. You and your principal investigators cannot be employed by any for-profit, commercial company in the radiologic sciences. 6. You cannot submit more than one grant application to the RSNA R\&E Foundation a year and cannot have a concurrent RSNA grant. 7. Funding from other grant sources must be approved by Foundation staff if it wasn't described in the original research plan

Level of Study: Research

Type: Grant for various aspects of field research and conservation projects in primate habitat countries

Value: US\$75,000 will be awarded for a year

Frequency: Annual

Country of Study: Any country

Application Procedure: Elaborated information on grants will be available in the following link. www.rsna.org/ research/funding-opportunities/research-grants/research-scholargrant

Closing Date: 15 January

Funding: Private

\section{For further information contact:}

820 Jorie Blvd., Suite 200, Oak Brook, IL 60523-2251, United States of America

Email: membership@rsna.org

\section{Research Seed Grant}

Purpose: This R\&E Foundation Research Seed Grant gives investigators around the world the chance to define objectives and test hypotheses in preparation for larger grant applications at corporations, foundations and government agencies

Eligibility: Any investigator from anywhere in the world with an academic appointment may apply for this grant, as long as you are an RSNA member. If you're a non dues-paying member, your scientific advisor or your co-investigator must be a dues-paying member. You must also meet the following criteria: All applicants; 1 . You must hold a full-time faculty position in a radiology, radiation oncology or nuclear medicine department at an educational institution. 2 . If you aren't currently a full-time faculty member, but will be by the time funding starts, a letter from the department chair must be included in your application. 3. You cannot have been a principal investigator on a grant or contract totaling more than US\$60,000 in a single year. This includes single and combined grants and contracts from government, private and commercial sources. 4. You and your principal investigators cannot be employed by any for-profit, commercial company in the radiologic sciences. 5. Funding from other grant sources must be approved by foundation staff if it wasn't described in the original research plan

Level of Study: Professional development, Research

Type: Research grant

Value: Upto US $\$ 40,000$ for a one-year project

Frequency: Annual

Country of Study: Any country

Application Procedure: Applications should describe the unique nature of the research effort independent of existing research efforts. Our Research \& Education Foundation provides a critical source of support for investigators. Since the Foundation's inception we've awarded over 1,450 grants. That's more than US\$60 million in funding for radiology research and improving patient care

Closing Date: 15 January

Funding: Private

\section{For further information contact:}

820 Jorie Blvd., Suite 200, Oak Brook, IL 60523-2251, United States of America 
Tel: (1) 6305712670

Email: REFoundation@rsna.org

\section{Ragdale}

\section{Sybil Shearer Fellowship: Dancemakers}

Purpose: The Ragdale Foundation and the Morrison-Shearer Foundation are pleased to announce a fellowship opportunity for dancemakers

Eligibility: Applications are reviewed by Ragdale's Curatorial Board and staff as well as Morrison-Shearer Foundation Trustees. We seek applicants who are pursuing new creativity in dance and movement. This may include both emerging and established practitioners

Level of Study: Postgraduate

Type: Fellowship

Value: cash stipend US\$500

Frequency: Annual

Country of Study: Any country

Application Procedure: Evaluations of work are based on the following criteria: 1 . Work sample and statement show evidence of original, inventive and exciting new work. 2. Work sample demonstrates quality, technical proficiency, and is professionally presented. 3. Artist's statement and resumé show evidence that the applicant's work is reflective of continued, serious, and exceptional aesthetic investigation in the chosen medium. 4. Work plan demonstrates that the artist will maximize the benefits of a fellowship at Ragdale. 5. References reflect the artist's ability to work well in an artist community Closing Date: 15 May

Funding: Private

\section{For further information contact:}

1260 N. Green Bay Road, Lake Forest, IL 60045, United States of America

Tel: $\quad$ (1) 8472341063

Email: info@ragdale.org

\section{Rebecca Skelton Fund}

Dance Department Administrator, University of Chichester, Bishop Otter Campus, College Lane, Sussex PO19 6PE, Chichester, United Kingdom

Tel: $\quad$ (44) 1243816485

Fax: (44) 1243816080
Email: rebeccaskeltonfund@chi.ac.uk

Website: www.rebeccaskeltonfund.org

Contact: The Rebecca Skelton Fund Administrator

The fund provides financial assistance towards the cost of postgraduate dance study in experiential/creative work to include dance improvization and those training methods such as Skinner Releasing Technique, Alignment Therapy, Feldenkrais Technique, Alexander Technique and other bodymind practices that focus on an inner awareness and use the proprioceptive communication system or an inner sensory mode.

\section{The Rebecca Skelton Scholarship}

Subjects: Music and performing arts

Purpose: To assist students to pursue a course of specific or advanced performance studies or an appropriate dance research and performance

Eligibility: Open to anyone pursuing dance studies at postgraduate level

Level of Study: Doctorate, Postdoctorate, Postgraduate, Professional development, Research

Type: Scholarships and fellowships

Value: UK $£ 500$

Frequency: Annual

Country of Study: United Kingdom

No. of awards offered: 9

Application Procedure: Application form on request

Closing Date: 12 January

Funding: Foundation

Contributor: The Rebecca Skelton Fund

No. of awards given last year: 5

No. of applicants last year: 9

For further information contact:

Email: artsresearch@chi.ac.uk

\section{Regent's Park College}

\section{Regent's Park College: Aziz Foundation Scholarship}

Subjects: Humanities, Arts or Social Science

Purpose: In association with Regent's Park College, the Aziz Foundation is offering a scholarship worth up to $£ 25,000$ for a student who is undertaking, or has been accepted for, 
a Master's degree in the humanities, arts or social sciences at the University of Oxford

Eligibility: 1. Applicants should: be active within a Muslim community and their wider community, and demonstrate a desire to develop intellectual skills within a multi-faith and secular environment. 2. Applicants will be able to demonstrate long-term commitment to community/societal development and working for good relations through effecting public policy; and be eligible for Home

Level of Study: Postgraduate

Type: Scholarship

Value: Up to $£ 25,000$ per year

Frequency: Annual

Country of Study: Any country

Closing Date: 31 March

Funding: Private

\section{For further information contact:}

Regent's Park College, Pusey Street, OX1 2LB, Oxford, United Kingdom

Email: academic.administrator@regents.ox.ac.uk

Contact: Ms Bailey Thomas, Academic Administrator

\section{The Pamela Sue Anderson Studentship for the Encouragement of the Place of Women in Philosophy}

Subjects: The studentship will be used to fund the tuition of one student and will be tenable for as long as the selection committee deems appropriate, subject to the condition that it shall not be tenable beyond the duration of the student's postgraduate studies at the University of Oxford

Purpose: Regent's Park College is offering a postgraduate studentship who is currently engaged in or has been accepted for post graduate study in the University of Oxford

Level of Study: Postgraduate

Type: Studentship

Frequency: Annual

Country of Study: Any country

Application Procedure: (i) covering letter, explaining how the candidate's proposed research relates to the vision of the studentship; (ii) current CV, including the names and contact details of two referees; (iii) research proposal; (iv) writing sample of no more than 5,000 words

Closing Date: 5 April

Funding: Private

\section{For further information contact:}

Pusey Street, OX1 2LB, Oxford, United Kingdom
Email:
enquiries@regents.ox.ac.uk
Contact: Bailey Thomas, Academic Administrator

\section{Regent's University London}

Inner Circle, NW1 4NS, London, United Kingdom

Contact: Regent's University London

Regent's University London is a private non-profit university located in London, United Kingdom. Regent's University is only the second institution in the United Kingdom that was granted the status of a private university.

\section{Pakistan Fashion Journalism Scholarship}

Subjects: Fashion Journalism

Purpose: An offer for students entering into MA programme Eligibility: Pakistani students are eligible to apply for this scholarship. Scholarship can be taken in the United Kingdom. To enter the competition for the OK! Pakistan Fashion Journalism Scholarship, you should first meet all of the following criteria: You are a Pakistani national holding a Pakistani passport; You have achieved at least an upper second class (2:1) United Kingdom honours undergraduate degree (or its international equivalent from a recognised institution); You hold an offer of a place on the MA Fashion (Journalism) programme

Type: Scholarship

Value: $£ 4,000$ towards fees for one standard programme duration

Country of Study: United Kingdom

Application Procedure: For more details, visit www. regents.ac.uk/study/scholarships-funding-and-bursaries/okpakistan-fashion-journalism-scholarship

Closing Date: 30 June

Funding: Private

\section{For further information contact:}

Email: enquiries@regents.ac.uk

\section{Robert McKee International Screenwriting Scholarships}

Level of Study: Graduate

Type: Scholarship

Value: $£ 7,000$ 
Country of Study: Any country

Closing Date: 30 June

For further information contact:

Email: contact@mckeestory.com

\section{The Dean of Humanities, Arts \& Social Sciences Excellence Scholarship}

Subjects: The Dean of Humanities, Arts \& Social Sciences Excellence Scholarship cannot be transferred to another undergraduate programme. In order to maintain the scholarship for the full duration of your studies, you must pass each module at the first attempt with a mark of at least $60 \%$

Purpose: The Dean of the Faculty of Humanities, Arts \& Social Sciences has established three scholarships that celebrate the University's independent, cosmopolitan and enterprising spirit

Level of Study: Graduate

Type: Scholarship and award

Value: The Scholarship award will cover a quarter of the tuition fees for the selected course

Frequency: Annual

Country of Study: Any country

Application Procedure: Applications must be emailed to: scholarships@regents.ac.uk

Closing Date: 31 May

Funding: Private

Additional Information: For any queries, please contact: Regent's University London, Tel: (44) 207487 7505, Email: enquiries@regents.ac.uk

\section{For further information contact:}

Email: scholarships@regents.ac.uk

\section{Regional Institute for Population Studies}

University of Ghana, PO Box 96, Legon, Accra, Ghana

$\begin{array}{ll}\text { Tel: } & \text { (233) } 21500381 \text { ext. } 3418 \\ \text { Fax: } & \text { (233) } 21500273 \\ \text { Email: } & \text { rips@libr.ug.edu.gh } \\ \text { Contact: } & \text { Director }\end{array}$

The Regional Institute for Population Studies organises training courses leading to the award of MA, MPhil and
$\mathrm{PhD}$ degrees, seminars and workshops. It also provides advisory services to member states on request, and facilities for students and research workers, as well as conducting research into population studies and related fields in the English speaking countries of Africa, focusing on level and trends of population growth, morbidity and mortality, reproduction, family formation, gender and the status of women, population structure and distribution, migration, and the interrelationship between population and development.

\section{Respective Government Fellowships}

Subjects: Population studies

Purpose: To enable Fellows to obtain advanced training through study or research leading to a Master of Arts, Master of Philosophy or PhD degree

Eligibility: Open to English speaking Sub-Saharan Africans, nominated by their governments, who are capable of pursuing a course of study or research using English as a medium of expression. Candidates should have a good first degree in population studies for the Master of Arts degree course or the Master of Population Studies degree, a Master of Arts in population studies or its equivalent for the Master of Philosophy degree, a Master of Philosophy in population studies or its equivalent for a $\mathrm{PhD}$ course

Level of Study: Doctorate, Postgraduate

Type: Fellowship

Value: Approx. US $\$ 13,840$ per year including stipend, fees, costs for books, minor equipment and production of dissertations and theses

Length of Study: At least 1 year for Master of Arts, at least 18 months for MPhil and 36 months for PhD

Frequency: Annual

Study Establishment: Regional Institute for Population Studies at the University of Ghana

Country of Study: Ghana

No. of awards offered: 22

Application Procedure: United Nations Fellows must complete an application form, available at any United Nations Development Programme Office in the capital city of each English speaking Sub Saharan African country, through which all applications should be routed. Applications must be filled out in triplicate and submitted together with the relevant admission requirement through the government ministry responsible for recruiting candidates for the Institute. Non United Nation Fellows should send an application letter directly to the Director of the Institute. All seven students were sponsored through country programme budgets of governments of three of the member states of the Institute

Closing Date: 30 June

Funding: Government 
No. of awards given last year: 13

No. of applicants last year: 22

Additional Information: 20 of last year's candidates were sponsored directly by the Institute and 10 through country programme budgets of governments of four of the member states of the Institute

\section{For further information contact:}

Tel: $\quad$ (233) 217738906

Fax: (233) 21772829

Email: fo.gha@undp.org

Contact: UNFPA

\section{Religious Scholarships}

\section{American Atheists Chinn Scholarships}

Subjects: All subjects

Purpose: American Atheists is proud to award two Chinn Scholarships for LGBT Atheist Activism. These scholarships recognize activism in the area of LGBT equality. You do not have to be a member of the LGBT community to receive this scholarship; allies are encouraged to apply

Eligibility: 1. High school seniors or current college students.

2. Full-time graduate and law school students. 3. Applicants must be atheists. 4. Have a minimum cumulative GPA of at least 2.5

Level of Study: Graduate

Type: Scholarship

Value: US\$500

Length of Study: 1 year

Frequency: Annual

Country of Study: New Zealand

Application Procedure: Apply online

Closing Date: 3 February

Funding: Foundation

\section{For further information contact:}

P.O. Box 158, Cranford, NJ 07016, United States of America

Tel: (1) 9082767300

Email: scholarship@atheists.org

\section{American Atheists O'Hair Award}

\section{Subjects: All subjects}

Purpose: The American Atheists awards a US\$1,000 O’Hair Scholarship to an atheist student attending college or university. The award is given every year at the American Atheists
National Convention. The Student Activist Scholarship program was founded by Life Members Barbara J. Baldock, Dr. Phillip Butler, Lillian B. Ramsden, Rice O'Dell and Irving Yablon

Eligibility: The scholarship can be used by a current college student or by high school student entering college the upcoming year. Additionally, full-time graduate and law school students are eligible for the scholarship. Applicants must be atheists and have a cumulative GPA of 2.5 or better. Applicants are judged based on their actions as atheists and activists Level of Study: Graduate

Type: Award

Value: US $\$ 1,000$

Length of Study: 1 year

Frequency: Annual

Country of Study: New Zealand

Application Procedure: Apply online

Closing Date: 26 February

Funding: Foundation

\section{For further information contact:}

P.O. Box 158, Cranford, NJ 07016, United States of America

Tel: (1) 9082767300

Email: scholarships@atheists.org

\section{Anna Schiller Scholarship}

Purpose: To be eligible for the Anna Schiller Memorial Scholarship, you must be a Rockford Christian High School graduating senior who demonstrates a strong commitment to improving the quality of life for people in their school, community and/or world at large through their community service and demonstrates the same strong love for others that Anna exemplified through her life. Minimum GPA of 2.0/4.0 is required. For more information or to apply, please visit the scholarship provider's website

Level of Study: Graduate

Type: Scholarship

Frequency: Annual

Country of Study: New Zealand

Closing Date: 1 February

Funding: Foundation

\section{For further information contact:}

946 North Second Street, Rockford, IL 61107, United States of America

Tel: (1) 8159622110

Email: slambert@cfnil.org 


\section{Associated Women for Pepperdine (AWP) Scholarship}

Purpose: The Associated Women for Pepperdine (AWP) was established in 1958 and is the largest, most active women's group supporting colleges and universities in Southern California. For over 50 years members have been primary contributors to scholarships for Christian students and have forged a strong link between the University and the Churches of Christ across the country

Eligibility: Current, active member of a Church of Christ congregation. The Associated Women for Pepperdine (AWP) awards a number of scholarships annually on a renewable basis to active members from the Churches of Christ

Level of Study: Graduate

Type: Scholarship

Value: US $\$ 5,000$

Length of Study: 1 year

Frequency: Annual

Country of Study: New Zealand

Application Procedure: Apply online

Closing Date: 15 February

Funding: Foundation

\section{For further information contact:}

Tel: $\quad$ (1) 3105064392

Email: admission-seaver@pepperdine.edu

\section{Republic of South Africa}

\section{Azerbaijan: Azerbaijan Diplomatic Academy University Scholarship}

Subjects: diplomacy, public and international affairs, business, humanities, sciences and system engineering

Purpose: The Government of the Republic of Azerbaijan and ADA University are offering scholarships to foreign students. The ADA University is committed to grooming world class leaders

Eligibility: Be South African citizens in good health, with a strong academic record. 1. Meet the entry criteria for their selected programme at the ADA University. 2. Meet the minimum academic requirement for entry into a similar programme at a South African university. 3. Applicants must be proficient in English

Level of Study: Postgraduate

Type: Scholarship

Value: offers tuition fees, travel expenses, medical benefits and monthly stipend
Frequency: Annual

Country of Study: Any country

Application Procedure: Information on the application process is available on the website. www.ada.edu.az/en-us/ pages/admission_fellowships.aspx

Closing Date: 1 July

Funding: Private

\section{For further information contact:}

Email: admissions@ada.edu.az

\section{Research Corporation for Science Advancement}

4703 E Camp Lowell Drive, Suite 201, Tucson, AZ 85712, United States of America

Tel: $\quad$ (1) 5205711111

Fax: (1) 5205711119

Email: awards@rescorp.org

Website: www.rescorp.org

Contact: Editor, Science Advancement Programme

The Research Corporation (United States of America) was one of the first United States foundations, and is the only one wholly devoted to the advancement of academic science. An endowed organization, it makes grants totalling US $\$ 5,000,000-7,000,000$ annually for independently proposed research in chemistry, physics and astronomy at United States and Canadian colleges and universities.

\section{Research Corporation (United States of America) Research Innovation Awards}

Subjects: Physics, chemistry or astronomy

Purpose: To assist innovative research programmes for faculty of PhD granting departments

Eligibility: Open to faculty members whose first tenure track position began in either the preceding or the current calendar year are eligible to apply

Level of Study: Doctorate

Type: Research grant

Value: US $\$ 35,000$ for equipment and supplies, graduate stipends and some other expenses. The award does not cover overheads

Frequency: Annual

Study Establishment: Research universities with $\mathrm{PhD}$ granting departments of physics, chemistry and astronomy 
Country of Study: United States of America or Canada

No. of awards offered: 200

Application Procedure: Applicants must complete an application form. Guidelines and an application request forms are available from the website

Closing Date: 1 May

Funding: Private

Contributor: Foundation endowment

No. of awards given last year: 45

No. of applicants last year: 200

Additional Information: Research proposals that transcend the ordinary and promise significant discoveries are sought after

\section{For further information contact:}

Email: awards@ria.ie

\section{Research Council of Norway}

Stensberggata 26, PO Box 2700, St Hanshaugen, Oslo, N 0131, Norway
Tel:
(47) 22037000
Fax:
(47) 22037001
Email: info@forskningsradet.no
Website: www.forskningsradet.no

The Research Council of Norway is a strategic body for Norwegian research and a central advisory body to the government on issues concerning general research policy as well as the development of science and technology. The Council bears overall responsibility for national research strategy and manages nearly one third of the public sector research funding. One of the principal tasks of the Research Council is to promote co-operation and co-ordination among Norwegian academic institutions. Other important objectives include raising the general level of knowledge in society and encouraging innovation in industry and the public sector. The Research Council identifies important fields of research, allocates funds and evaluates research and development.

\section{Research Council of Norway Senior Scientist Visiting Fellowship}

Subjects: Agriculture, forestry, veterinary medicine, and related fields

Purpose: To enable Norwegian research institutions to receive foreign scientists to participate in research groups, discuss research arrangements and give lectures within their special fields

Eligibility: Open to well established and internationally recognised scientists who are at a professional or equivalent level

Level of Study: Professional development

Type: Fellowship

Value: Norwegian krone 25,000 per month for the first two months, Norwegian krone 10,000 for each succeeding month. Travelling expenses may also be defrayed

Length of Study: 1-12 months

Frequency: Annual

Study Establishment: A Norwegian research institution

Country of Study: Norway

Application Procedure: Applications must be filed by Norwegian institutions, so individual scientists should contact the Norwegian research institution or university department of their choice

Closing Date: Varies, please contact the Research Council for details

Funding: Government

Additional Information: The Research Council of Norway also administers the following: Research Programmes of the European Union (EU), Bilateral Scholarship Agreements, and the Nordic Scheme for the Baltic Countries and North West Russia

For further information contact:

Email: post@forskningsradet.no

\section{Reserve Bank of New Zealand}

2 The Terrace, PO Box 2498, Wellington 6140, New Zealand

Tel: $\quad$ (64) 44722029

Fax: (64) 44738554

Email: rbnz-info@rbnz.govt.nz

Website: www.rbnz.govt.nz

The Reserve Bank of New Zealand is New Zealand's central bank. They promote a sound and dynamic monetary and financial system. They work towards our vision by operating monetary policy to achieve and maintain price stability, assisting the functioning of a sound and efficient financial system, meeting the currency needs of the public, overseeing and operating effective payments systems and providing effective support services to the Bank. 


\section{Reserve Bank of New Zealand Scholarships for International Students}

Subjects: Economics, finance and banking

Purpose: Scholarships are available for pursuing honours, master's or final year of $\mathrm{PhD}$ degree level at a New Zealand University

Eligibility: Applicants must be studying full time at a New Zealand University and be legally entitled to work in New Zealand. Students must have attained at least B + average and be studying full time over the academic year (February to November). Applicants must have majoring in Economics, Finance or Banking and they should be entering their honours, Master's or final year of $\mathrm{PhD}$ study

Type: Scholarship

Value: The value of each scholarship will be $\$ 10,000$

Country of Study: New Zealand

Application Procedure: The mode of applying is by email Closing Date: 15 January

Contributor: The Reserve Bank of New Zealand

Additional Information: Successful applicants will be asked to attend a half day interview process at the Bank in Wellington. This typically takes place in the beginning of February

For further information contact:

Email: recruitment@rbnz.govt.nz

\section{Resuscitation Council (United Kingdom)}

5th Floor, Tavistock House North, Tavistock Square, WC1H 9HR, London, United Kingdom

Tel: $\quad$ (44) 2073884678

Fax: (44) 2073830773

Email:_enquiries@resus.org.uk

Website: www.resus.org.uk

Contact: Dr Sara Harris, Assistant Director

The Resuscitation Council (United Kingdom) is the expert advisory body on the training and practice of resuscitation in the United Kingdom. It also actively pursues and promotes research in the field of resuscitation medicine.

\section{Resuscitation Council (United Kingdom) Research \& Development Grant}

Subjects: All aspects of the science practice and teaching of resuscitation techniques
Purpose: To provide grants up to a maximum of $£ 20,000$ for capital costs, data analysis and administrative support for research into the science and practice of resuscitation medicine Type: Grant

Frequency: Annual

Country of Study: Any country

No. of awards offered: 13

Closing Date: 30 May

No. of awards given last year: 5

No. of applicants last year: 13

For further information contact:

Email: enquiries@resus.org.uk

\section{Rheumatology Research Foundation}

2200 Lake Boulevard NE, Atlanta, GA 30319, United States of America

Tel: $\quad$ (1) 4046333777

Fax: (1) 4046331870

Email: foundation@rheumatology.org

Website: www.rheumatology.org

Contact: Sarah Barksdale, Senior Specialist, Awards and Grants

The American College of Rheumatology (ACR) is the professional organization of rheumatologists and associated health professionals who share a dedication to healing, preventing disability and curing more than 100 types of arthritis and related disabling and sometimes fatal disorders of the joints, muscles and bones.

\section{American College of Rheumatology REF Rheumatology Scientist Development Award}

Subjects: Arthritis and rheumatic diseases

Purpose: To encourage qualified physicians without significant prior research experience to embark on careers in biomedical and/or clinical research in arthritis and rheumatic diseases

Eligibility: Candidates must be an ACR or ARHP member, have a doctoral level degree, must be clinician scientists

Level of Study: Doctorate, Postdoctorate, Professional development, Research

Type: Award

Value: US $\$ 50,000$ for first year, US $\$ 75,000$ for second year and US\$100,000 for third year 
Length of Study: 3 years

Frequency: Annual

Country of Study: United States of America

No. of awards offered: 12

Application Procedure: Application forms are available on website

Closing Date: 2 August

Funding: Foundation

Contributor: Centocor Inc

Additional Information: For any questions regarding eligibility, contact the REF

For further information contact:

Email: ref@rheumatology.com

\section{American College of Rheumatology/REF Arthritis Investigator Award}

\section{Subjects: Arthritis}

Purpose: To provide support to physicians and scientists in research fields related to arthritis for the period between the completion of postdoctoral fellowship training and establishment as an independent investigators

Level of Study: Research

Type: Award

Value: US $\$ 75,000$ for the first 2 years and US $\$ 90,000$ per year after renewal

Length of Study: 2-4 years

Frequency: Annual

Country of Study: United States of America

Application Procedure: Application forms are available on website

Closing Date: 1 September

Funding: Foundation

Contributor: The Arthritis Foundation

For further information contact:

Email: acrnominations@rheumatology.org

\section{Career Development in Geriatric Medicine Award}

Subjects: Geriatrics and rheumatology

Purpose: To support career development for junior faculty in the early stages of their research career

Eligibility: To be eligible for the award, the candidate must: be a member of the ACR; have completed a rheumatology fellowship leading to certification by the ABIM and be within the first 3 years of his/her faculty appointment; and possess a faculty appointment at the time of the award. Award applicant must be a citizen or non-citizen national of the United States of America, or be in lawful possessions of a permanent resident card. Individuals on temporary $(\mathrm{J} 1, \mathrm{H1})$ or student visas are not eligible Level of Study: Doctorate, Professional development, Research

Type: Research award

Value: US $\$ 75,000$ per year plus US $\$ 3,000$ in travel grants Length of Study: 2 years

Frequency: Annual

Country of Study: United States of America

No. of awards offered: 1

Application Procedure: Application forms are available on website www.rheumatology.org/foundation/index.asp

Closing Date: 1 August

Funding: Foundation

Contributor: Association of Subspecialty Professors

No. of awards given last year: 1

No. of applicants last year: 1

\section{For further information contact:}

Email: ysong@hrsa.gov

\section{Fellowship Training Award}

Subjects: Rheumatic diseases

Purpose: The purpose of this award is to provide support to fellows in rheumatology to help ensure that a diverse and highly trained workforce is available to provide competent care to those affected by rheumatic diseases

Eligibility: Only training directors at ACGME-accredited institutions in good standing may apply. The rheumatology fellowship training programme director at the institution will be responsible for the selection and appointment of trainees. Award applicant must be a citizen or non-citizen national of the United States of America, or be in lawful possession of a permanent resident card. Individuals on temporary $(\mathrm{J} 1, \mathrm{H} 1)$ or student visas are not eligible

Level of Study: Doctorate

Type: Fellowship

Value: Recipients will receive US\$50,000 to support the salary of any fellow. The award is paid directly to the sponsoring institution in 2 equal installments in July and January Length of Study: 1 year

Frequency: Annual Country of Study: United States of America

No. of awards offered: 39

Application Procedure: www.rheumresearch.org/educationand-training-awards\#AmgenFTA

Closing Date: 1 May

Funding: Corporation, Foundation

Contributor: Amgen, Inc 
No. of awards given last year: 23

No. of applicants last year: 39

For further information contact:

Email: acmgf@acmgfoundation.org

\section{Lawren H. Daltroy Health Professional Preceptorship}

Subjects: Rheumatology

Purpose: Develop a more qualified and trained health professional workforce in order to improve patient-clinician interactions

Eligibility: Preceptee must meet citizenship requirements outlined by the Rheumatology Research Foundation Awards and Grants policies. Preceptee must be citizens or non-citizen nationals of the United States or in lawful possession of a permanent resident card. Other individuals on temporary $(\mathrm{J} 1, \mathrm{H1})$ or student visas are not eligible. Preceptor must be an ARHP member. This award is not intended for physicians Level of Study: Graduate, Postgraduate, Professional development

Type: Scholarship

Value: Up to US\$12,000 for 1 year

Length of Study: 1 year

Frequency: Annual

Country of Study: United States of America

No. of awards offered: 3

Application Procedure: Check the following document for further info. www.rheumresearch.org/file/awards/2018/ Daltroy_RFA_FY20.pdf

Closing Date: 1 May

Funding: Corporation

Contributor: Funding for this award is made possible through an endowment by Rheuminations, Inc

No. of awards given last year: 1

No. of applicants last year: 3

Additional Information: Please check website www. rheumresearch.org

\section{For further information contact:}

Email: Foundation@rheumatology.org

\section{Medical and Graduate Student Preceptonship}

Subjects: Rheumatology

Eligibility: Students enroled in LOME or AOA COCA accredited medical schools, undergraduate students who have been accepted into medical school, students enroled in an accredited graduate school, or undergraduate students who have been accepted into graduate school, are eligible to apply Level of Study: Graduate, Postdoctorate, Postgraduate, Research

Value: US $\$ 2,000-4,000$ plus complimentary registration and up to US\$1,000 in travel expenses to attend the ACR/ARHP Annual Meeting

Length of Study: 1 academic year

Frequency: Annual

Country of Study: United States of America

Application Procedure: Only completed applications submitted online by the deadline will be accepted

Closing Date: 4 Cycles - 1 February, 2 May, 1 August, 1 November

Funding: Foundation

Contributor: Rheumatology Research Foundation

No. of awards given last year: Up to 30

\section{For further information contact:}

Email: Foundation@rheumatology.org

\section{Scientist Development Award}

Subjects: Rheumatology

Purpose: To provide a training programme to rheumatology fellows or rheumatologists in the early stages of their career on aspects of clinical investigations through a structured, formal training programme

Eligibility: Applicant must meet citizenship requirements outlined by the Rheumatology Research Foundations Awards and Grant policies, be an active member of the ACR or ARHP at the time of submission, have a doctoral level degree, and be affiliated with an accredited graduate or medical school. Applicant must be able to commit at least $75 \%$ full-time professional effort to research, career development and other scholarly activities. Candidates may not spend more than $25 \%$ effort in clinical and/or teaching activities. Former or current principal investigators of research grants (at the $\mathrm{K}$ level or higher, including institutional $\mathrm{K}$ ) and past awardees of this or equivalent Foundation grants are NOT eligible to apply

Level of Study: Doctorate, Postdoctorate, Professional development, Research

Type: Award

Value: US $\$ 50,000$ for first year, US $\$ 75,000$ for second year and US $\$ 100,000$ for third year

Length of Study: Up to 2 years

Frequency: Annual

Country of Study: United States of America 
No. of awards offered: 36

Application Procedure: www.rheumresearch.org/careerdevelopment-research-awards\#SDA

Closing Date: 1 July

Funding: Foundation

Contributor: Rheumatology Research Foundation

No. of awards given last year: 8

No. of applicants last year: 36

Additional Information: www.rheumresearch.org

\section{For further information contact:}

Email: apply@heart.org

\section{Rhode Island Foundation}

\section{Cataract Fire Company \#2 Scholarship}

Purpose: This scholarship is open to residents of Warwick, Rhode Island, who are entering their first year of a two-year, four-year, or vocational/technical postsecondary institution. Students must demonstrate financial need

Eligibility: 1. Must be a high school senior who is entering his/her first year of a two-year, four-year, or vocational/ technical postsecondary institution. 2. Must be a resident of Warwick, Rhode Island. 3. Must be a citizen of United States of America. 4. This award is for United States students

Level of Study: Graduate

Type: Scholarship

Value: US $\$ 1,458$

Frequency: Annual

Country of Study: United States of America

Application Procedure: Applications are available on the Rhode Island Foundation website. The student must click on the "Scholarship/Fellowship Opportunities" link and then search for his/her desired scholarship to access the application. In addition to a completed application, the student must submit the following documents: a copy of his/her financial aid award letter; his/her official high school transcript; a resume or a list of activities in which he/she participates; a typed double-spaced essay of 300 words or less describing what he/she hopes to be doing in his/her professional life 10 years from now; and a copy of his/her final Student Aid Report (SAR), which is provided to the student after filing the FAFSA (Free Application for Federal Student Aid)

Closing Date: 5 April

Funding: Foundation

\section{For further information contact:}

34 Warwick Lake Ave., Warwick, RI 02889, United States of America

Tel: (1) 4014274011

Email: rbogert@rifoundation.org

\section{Major Jeremiah P. Murphy Scholarship}

Purpose: This scholarship is open to children of active, retired, or deceased Providence (RI) police officers who are or will be attending postsecondary institutions offering two-year associate's or four-year college degree

Eligibility: 1. Must be a resident of Rhode Island. 2. Must be a citizen of United States of America. 3. Must be attending or planning to attend a postsecondary institution offering a two-year associate's or a four-year college degree. 4. Must be the child of an active, retired, or deceased Providence, Rhode Island, police officer. 5. This award is for United States students Level of Study: Graduate

Type: Scholarship

Value: US $\$ 2,500$

Frequency: Annual

Country of Study: United States of America

Application Procedure: The application deadline date has not yet been finalized for this year, but is expected to remain the same as last year. The deadline date shown here is tentative based on last year's date. Please check back in November for a refreshed application deadline date. Applications are available on the Rhode Island Foundation website. The student must click on the "Scholarship/Fellowship Opportunities" link and then search for his/her desired scholarship to access the application. As part of the online application, the student must upload the following required documents: a completed 'Financial Information Worksheet' (accessible for download in the application); a copy of his/her SAR (Student Aid Report), which is generated after filing the FAFSA (Free Application for Federal Student Aid); the most recent version of his/her student transcript (unofficial accepted); an essay of one page or less on the topic listed on the application; proof of eligible parental employment

Closing Date: 6 April

Funding: Foundation

\section{For further information contact:}

1 Union Station, Providence, Rhode Island 02903, United States of America

Tel: $\quad$ (1) 4014274011

Email: rbogert@rifoundation.org 


\section{Rhodes College}

2000 North Parkway, Memphis, TN 38112-1690, United States of America

Tel: $\quad$ (1) 9018433000

Email: registrar@rhodes.edu

Website: www.rhodes.edu

Rhodes, founded in 1848 , seeks to graduate students with a lifelong passion for learning, a compassion for others, and the ability to translate academic study and personal concern into effective leadership and action in their communities and world.

\section{Watson Fellowship}

Subjects: All subjects

Purpose: To offer college graduates a year of independent study and travel outside the United States

Eligibility: Candidates must be graduating seniors to apply; United States citizenship NOT required

Type: Fellowship

Value: US $\$ 25,000$

Length of Study: 1 year

Frequency: Annual

Application Procedure: A fellowship form along with a project application proposal and details in not more than 5 pages should be submitted electronically

Closing Date: Early October (Internal deadline)

Contributor: Thomas J. Watson Foundation

\section{For further information contact:}

Watson Fellowship Program, 293 South Main Street, Providence, RI, United States of America

Tel: $\quad$ (1) 4012741952

Fax: (1) 4012741954

Email: tjw@watsonfellowship.org

Contact: Thomas J

\section{Rhodes Trust}

\section{Rhodes Scholarship}

Subjects: The Rhodes Scholarship is an international postgraduate award for students to study at the University of Oxford
Purpose: Rhodes's vision in founding the Scholarship was to develop outstanding leaders who would be motivated to 'fight the world's fight' and to 'esteem the performance of public duties as their highest aim', and to promote international understanding and peace

Eligibility: At the time of application, an applicant must be: a citizen of the United States OR a lawful permanent resident of the United States OR a U.S. resident with DACA status on April 15 in the year of application. Eligible to apply through one of the 50 states, the District of Columbia, or one of the U.S. territories: either in the state or territory where the applicant was legally resident on April 15 in the year of application, or where the applicant will have received at least two years of college training and a bachelor's degree before October 1 in the year following election. At least 18 but not yet 24 years of age (i.e., the applicant must still be 23 on October 1 in the year of application)

Level of Study: Postgraduate

Type: Scholarship

Value: Fees are paid directly by the Trust to the College and University

Length of Study: 2 year

Frequency: Varies

Country of Study: United Kingdom

Application Procedure: Apply online rhodes.embark.com/ auth/login

Closing Date: 1:59 PM U.S. Eastern Time on the first Wednesday of October each year

Funding: Foundation

\section{For further information contact:}

Tel: (64) 44758403

Email: scholarships-cf@universitiesnz.ac.nz

\section{Rhodes University}

PO Box 94, Grahamstown, 6139, South Africa

Tel: $\quad$ (27) 466038055

Fax: (27) 466228822

Email: research-admin@ru.ac.za

Website: www.ru.ac.za/research

Contact: John Gillam, Manager

Rhodes University is a small university campus in Grahamstown with one of the highest research outputs per capita in South Africa. The University offers excellent undergraduate and postgraduate education, and fosters personal development and leadership as well as team, 
social and communication skills amongst its diverse student body.

\section{Hobart Houghton Research Fellowship}

Subjects: Economics

Purpose: To promote work of scientific value relevant to the economic problems of the Eastern Cape Province, Republic of South Africa, that could contribute to the betterment of the people of the region

Eligibility: Open to English speakers who hold at least a Master's degree in economics and who exhibit successful research experience

Level of Study: Doctorate, Postdoctorate

Type: Fellowship

Value: Rand 25,000

Length of Study: 2 months- 1 year

Frequency: Annual

Study Establishment: Rhodes University, Grahamstown

Country of Study: South Africa

No. of awards offered: 4

Application Procedure: Applicants must complete an application form, available from the Dean of Research or from the website

Closing Date: 30 September

Funding: Commercial

No. of awards given last year: 1

No. of applicants last year: 4

For further information contact:

Email: h.nel@ru.ac.za

Contact: Professor $\mathrm{H} \mathrm{Nel}$

\section{Ruth First Scholarship}

Subjects: Humanities, social science students whose fields of study are politics, sociology, philosophy, anthropology, economics, social policy, democracy studies, development studies, media studies, or studies in $\operatorname{cog}$ rate disciplines with a strong social and human rights orientation

Purpose: The scholarship is intended to support candidates whose research is in the spirit of Ruth First's life and work, poses difficult social questions, and links knowledge and politics and scholarship and action

Eligibility: For Masters or PhD study and black South African or Mozambican women candidates are particularly encouraged to apply

Level of Study: Doctorate, Postgraduate

Type: Scholarship
Value: South African 120,000 (PhD); Rand 90,000 per year (Master's)

Frequency: Annual

Study Establishment: Rhodes University, Grahamsdown

Country of Study: South Africa

No. of awards offered: 126

Application Procedure: Applicants to submit a letter of motivation (2 pages or more) as to why they would be a potentially suitable candidate for this award and how their proposed research will be within the spirit of Ruth First's work. In addition, an academic transcript, academic curriculum vitae and a copy of an identity document is required

Closing Date: 31 August

Funding: Private

Contributor: Donor and Investments

No. of awards given last year: 1

No. of applicants last year: 126

For further information contact:

Tel: $\quad$ (233) 466038755

Email: pgfinaid-admin@ru.ac.za

\section{Roberta Sykes Indigenous Education Foundation}

100 Botany Road, Alexandria, NSW 2015, Australia

Tel: $\quad$ (44) 293108400

Contact: The Roberta Sykes Indigenous Education Foundation

The group began by publishing an Aboriginal community newspaper, Koori Bina, which later became AIM (Aboriginal and Islander Message). BWA taught students of the Aboriginal and Islander Dance Theatre the skills to publish a small community newspaper; literacy, reporting, creative writing, editing, lay-out and administration, which eventually lead to the students taking over its publication. Over time, BWA broadened its work and funded a number of small enterprises that were established by Aboriginal women.

\section{Roberta Sykes Bursary}

Purpose: The Roberta Sykes Indigenous Education Foundation provides partial funding for Indigenous Australians to 
undertake short, executive education courses at leading overseas academic institutions

Eligibility: For eligibility and application details, please visit www.robertasykesfoundation.com/roberta-sykes-bursary. html

Type: Bursary

Value: The value of the Bursary is up to $\$ 20,000$

Country of Study: Australia

Application Procedure: Before applying for this scholarship, if any clarifications are required, contact the foundation using the link www.robertasykesfoundation.com/contact. html

Closing Date: 6 June; 25 July; 28 November

\section{For further information contact:}

Tel: (44) 293108400

\section{Roberta Sykes Scholarship}

Purpose: The Roberta Sykes Scholarship provides partial funding to Aboriginal and/or Torres Strait Islander postgraduate students who wish to undertake studies at recognised overseas universities

Eligibility: For eligibility details, please visit www.robertasy kesfoundation.com/roberta-sykes-scholarships.html. Usually have an undergraduate degree with a strong academic record; Be accepted into a postgraduate coursework or research degree at a recognised overseas university; Be of Aboriginal and/or Torres Strait Islander descent, identify as Aboriginal and/or Torres Strait Islander and be accepted as such by the community in which they live or have lived; Be able to demonstrate that alongside a Roberta Sykes Scholarship, they will have sufficient funds to support themselves during the course of their postgraduate degree (such as through another scholarship, private sponsorship or personal funds); Be able to demonstrate that their studies will be of benefit to their community upon their return to Australia

Type: Scholarship

Value: The value of the Scholarship is up to $\$ 30,000$ per year Country of Study: Australia

Application Procedure: In order to contact for the elaborate information about the application. check the below link. www.robertasykesfoundation.com/contact.html

Closing Date: 28 March; 6 June; 25 July; 28 November

Additional Information: If you require further information or wish to discuss your application before submitting please contact the foundation at www.robertasykesfoundation.com/ contact.html

\section{For further information contact:}

Tel: (44) 293108400

\section{The Annual Aurora Indigenous Scholars International Study Tour}

Subjects: The Roberta Sykes Indigenous Education Foundation works closely with The Aurora Education Foundation to administer the Roberta Sykes scholarship, fellowship and bursary programs

Purpose: The Study Tour not only offers invaluable opportunities for students to gain insight into the realities of undertaking postgraduate study at these leading institutions but also provides the opportunity to travel with a group of like-minded students. The Study Tour involves meetings with key academics and administrators at each university, as well as current students in the areas of the participants' interest

Eligibility: 1. The Study Tour is open to applicants who have completed at least two years of their course of study and also to university graduates who wish to undertake further postgraduate study. 2. Each year, there is a competitive application process for the Study Tour. 3. The successful applicants will be chosen primarily on the basis of academic achievement

Level of Study: Postgraduate

Type: Scholarship

Value: Costs associated with travel, accommodation and meals are covered

Frequency: Annual

Country of Study: Australia

Application Procedure: To be considered, applicants must apply online via the Indigenous Scholarships Portal and upload the following documents: 1. A cover letter (including a personal statement about your background, career aspirations and reasons for wanting to go on the Tour). 2. A curriculum vitae. 3. An official transcript of all university results (including mid-year results, if available) Confirmation of Aboriginal or Torres Strait Islander descent through a signed written statement (including common seal if available) of an Aboriginal or Torres Strait Islander Heritage. 4. Association, Aboriginal or Torres Strait Islander Corporation or Land Council in the community where you live or have lived. 5. A high-resolution photo (headshot preferably) that could be used in promotional material, should you be selected to go on the Tour. 6. A scanned copy of your passport bio data page (if you have a valid passport)

Closing Date: 1 May

Funding: Private

Additional Information: For further information on the Study Tour, please please visit the Aurora Education Foundation website

\section{For further information contact:}

Email: scholarships@auroraproject.com.au 


\section{The Roberta Sykes Harvard Club Scholarship}

Subjects: Each Harvard graduate school or department has its own admissions criteria and deadlines. Before applying, prospective applicants should check the Harvard website (www. harvard.edu/admissions-aid) to clarify all deadlines and the exact requirements for admission to their chosen degree program

Purpose: The purpose of the award is to promote fellowship amongst alumni and to assist Australians wishing to study at Harvard

Eligibility: For eligibility details, please visit www.robertasy kesfoundation.com/roberta-sykes-harvard-club-scholarship. html

Type: Scholarship

Value: The value of the scholarship is up to $\$ 80,000$ per annum to be paid over the course of the Scholar's study

Country of Study: Australia

Application Procedure: Before applying, prospective applicants should check the Harvard website (www.harvard.edu/ admissions-aid) to clarify all deadlines and the exact requirements for admission to their chosen degree programme

Closing Date: Applications are still open

Contributor: Roberta Sykes Harvard Club

Additional Information: For more information on the club and its programs, please visit www.harvardclub.org.au

For further information contact:

Email: scholarships@auroraproject.com.au

\section{Rotterdam School of Management, Erasmus Graduate School of Business}

PO Box 1738, Rotterdam, NLD 3000 DR, Netherlands

Tel: $\quad$ (31) 104082222

Fax: (31) 104529509

Email: rsm@rsm.nl

Website: www.rsm.nl

Contact: Ms Connie Tai, Director of Recruiting \&

Admissions

\section{Holland Government Scholarship/upcoming year for school of management}

Purpose: The RSM scholarship will determine award recipient. The Holland Scholarship is financed by the Dutch Ministry of Education, Culture and Science
Eligibility: To be eligible, fulfill the following: 1. Your nationality is non-EEA. 2. You are a prospective student, starting your studies in the academic year. 3. You are applying for a full-time bachelor's or master's programme at RSM. 4. You meet the specific requirements of the programme you are applying for. 5. You do not have a degree from an educational institution in the Netherlands (excluding exchange programmes in the Netherlands). This content was originally published on After School Africa from www.afters choolafrica.com/13953/netherlands-fellowship-programmesnfp-developing-countries-phd-students/

Level of Study: Postgraduate

Type: Scholarship

Value: $€ 5,000$ for maximum of 12 months

Frequency: Annual

Country of Study: Any country

Application Procedure: First Step is to register for the Bachelor International Business Administration programme. Required documents are : A scholarship application letter in OLAF of maximum 1 A4 size page, including the following information. 1. an explanation why you would need a scholarship, comprising a description of academic excellence and if application other merits. 2. a clear financial plan, of how you are going to finance year 2 and 4 of IBA programme. 3. If applicable, certified copies of the scholarship granted

Closing Date: 31 January

Funding: Private

Contributor: The Dutch Ministry of Education, Culture and Science

\section{Rotterdam School of Management Erasmus University}

MBA Programmes, Burgemeester Oudlaan 50, 3062 PA Rotterdam, PO Box 1738, Rotterdam, NLD 3000 DR, Netherlands

$\begin{array}{ll}\text { Tel: } & \text { (31) } 104082222 \\ \text { Fax: } & \text { (31) } 104529509 \\ \text { Email: } & \text { info@rsm.nl } \\ \text { Website: } & \text { www.rsm.nl } \\ \text { Contact: } & \begin{array}{l}\text { Denise Chasney van Dijk, Financial Aid } \\ \\ \end{array} \\ & \text { Manager }\end{array}$

As one of the world's top business schools, RSM is a centre of excellence and innovation for management education and research. Our goal is to empower individuals to succeed amid the complexities of modern international commerce and become the business leaders of tomorrow. 


\section{Rotterdam School of Management Master of Business Administration Asia \& Australia Regional Scholarship}

Subjects: Business Management

Purpose: To assist candidates from the Asia \& Australasia Region in financing their MBA study in the Netherlands

Eligibility: The scholarship is open to high potential candidates who are a citizen or hold permanent residence status in one of the following listed countries: Australia, Bangladesh, Bhutan, Brunei, Burma, Cambodia, China, Fiji, Hong Kong, India, Indonesia, Japan, Kiribati, Laos, Macau, Malaysia, Micronesia, Mongolia, Nepal, New Zealand, Palau, Papua New Guinea, Philippines, Samoa, Singapore, Solomon Islands, Sri Lanka, Thailand, Timor-Leste, Tonga, Tuvalu, Vietnam, Yemen

Level of Study: MBA

Type: Scholarship

Value: 20\% tuition fee waiver

Length of Study: 12 months

Frequency: Annual

Study Establishment: Erasmus University

Country of Study: Netherlands

No. of awards offered: 36

Application Procedure: Complete application form to be considered

Closing Date: 30 September

Funding: Private

Contributor: RSM Erasmus University

No. of awards given last year: 1

No. of applicants last year: 36

Additional Information: Eligible to nationals of Asia and Australasia

For further information contact:

Email: info@rsm.nl

\section{Royal Academy of Engineering}

3 Carlton House Terrace, SW1Y 5DG, London, United Kingdom

Tel: $\quad$ (44) 2077660600

Fax: (44) 2079301549

Email: mark.bambury@raeng.org.uk

Website: www.raeng.org.uk

Contact: Dr Mark Bambury, Scheme Manager

The Royal Academy of Engineering's objectives may be summarized as the pursuit, encouragement and maintenance of excellence in the whole field of engineering in order to promote the advancement of the science, art and the practice of engineering for the benefit of the public.

\section{ExxonMobil Excellence in Teaching Awards}

Subjects: Chemical, petroleum and mechanical engineering, geology

Purpose: To encourage able young engineering and Earth science lecturers to remain in the education sector in their early years

Eligibility: Open to well-qualified graduates, preferably with industrial experience and full-time lecturing posts at Institutes of Higher Education in the United Kingdom. Applicants should have been in their current posts for at least 1 year. The post must include the teaching of chemical, petroleum or mechanical engineering to undergraduates through courses that are accredited for registration with professional bodies for qualifications such as chartered engineer. For applicants whose career path has been graduation at the age of 22 , followed by academic or industrial posts, the age limit is generally 32 years (at the closing date). Older candidates who have taken time out, e.g. for industrial experience, parenthood or voluntary service, will also be considered. Applicants should preferably be chartered engineers, or of equivalent professional status, or should be making progress towards this qualification

Level of Study: Postdoctorate

Type: Fellowship

Value: $A$ range of benefits in addition to the $£ 10,000$ prize

Length of Study: 12 months

Frequency: Annual

Study Establishment: The applicant's current university in the United Kingdom

Country of Study: United Kingdom

Application Procedure: Applicants must complete an application form

Closing Date: 31 October

Funding: Commercial

Contributor: Exxon Mobile

Additional Information: A brochure is available on request. Enquiries about Exxon mobile university contacts should be sent via email and please see the website for further details

\section{For further information contact:}

Email: bowbricki@raeng.co.uk 


\section{Royal Academy Engineering Professional Development}

\section{Subjects: Engineering}

Purpose: To ensure that the stills and knowledge of employees reflect the very latest in technological advances

Eligibility: Open to United Kingdom citizens with a degree or $\mathrm{HND} / \mathrm{HNC}$ in engineering or a closely allied subject. OND/ONC or City and Guilds Full Technological Certificate or NVQ level III qualifications are acceptable provided the individual has substantial industrial experience

Level of Study: Professional development

Type: Grant

Value: $£ 10,000$ and $£ 5,000$ and prospective applicants should indicate for which level of award they are applying

Length of Study: 1 year

Frequency: Annual

Country of Study: United Kingdom

Application Procedure: For further information please contact the scheme manager lan Bowbrick at the Academy

Closing Date: 24 October

Additional Information: Please see the website for further details

\section{For further information contact:}

Email:1an.bowbrick@raeng.org.uk

\section{Royal Academy Sir Angus Paton Bursary}

Subjects: Engineering for development and water and environmental management

Purpose: To study water and environmental management Eligibility: The bursary supports a suitably qualified engineer study a full-time Masters' degree course specifically related to water resources engineering or some other environmental technology

Level of Study: Postgraduate

Type: Bursary

Value: UK $£ 8,000$

Length of Study: 1 year

Frequency: Annual

Country of Study: United Kingdom

Application Procedure: For further information please contact the scheme manager Ian Bowbrick at the Academy

Closing Date: Offered all year round (check with website)

Funding: Private

Contributor: Sir Angus Paton

\section{For further information contact:}

Email: ian.bowbrick@raeng.org.uk

Contact: Ian Bowbrick

\section{Royal Academy Sir Henry Royce Bursary}

Subjects: Aerospace design, manufacture and management, automotive engineering design

Eligibility: Open to qualified engineers enrolled on part-time modular Master's courses

Level of Study: Postgraduate

Type: Bursary

Value: UK $£ 1,000$

Length of Study: 1 year

Frequency: Annual

Country of Study: United Kingdom

Application Procedure: For further information please contact the scheme manager Ian Bowbrick at the Academy

Closing Date: Offered all year round

Funding: Foundation

Contributor: Sir Henry Royce Memorial Foundation

Additional Information: Each awardee will receive a commemorative certificate and, on successful completion of their studies and award of the degree, a medal from the Sir Henry Royce Memorial Foundation

For further information contact:

Email: ian.bowbrick@raeng.org.uk

\section{Royal Agricultural University}

Royal Agricultural University, Gloucestershire, GL7 6JS, Cirencester, United Kingdom

Tel: $\quad$ (44) 1285652531

Fax: (44) 1285650219

Website: www.rau.ac.uk/

The Royal Agricultural University has always been at the forefront of agricultural education since 1845 .

\section{Africa Land and Food Masters Fellowship}

Subjects: This funding is provided for leadership training; the development of professional networks and supporting industrial experience, together with study opportunities on 
Master's programmes in agriculture, agri-business, food and rural development at the Royal Agricultural University

Eligibility: Fellowships are open to Africans from Sub-Saharan Africa who have experience in agriculture, agri-business, food or natural resource management; an interest in land reform; and a desire to make a strategic and sustainable contribution to Africa's development

Level of Study: Postgraduate

Type: Fellowship

Value: Since the Fellowship was launched in 2005, over $£ 1,800,000$ has been generously provided by the private sector, foundations and charities in support of the programme Country of Study: United Kingdom

Application Procedure: Nationals from sub-Saharan Africa are invited to apply for a Fellowship

Closing Date: 31 October

Funding: International office

\section{For further information contact:}

Email: african.fellowship-at-rau.ac.uk

\section{Royal College of Midwives}

15 Mansfield Street, W1G 9NH, London, United Kingdom

Tel: $\quad$ (44) 2073123643

Fax: (44) 2073123536

Email: info@rcm.org.uk

Website: www.rcm.org.uk

Contact: S E MacDonald, Education and Research Manager

The Royal College of Midwives is the major professional organization for midwives in the United Kingdom, and aims to contribute to the art and science of midwifery knowledge and practice. The RCM awards and scholarships provide opportunities for the development of good practice ultimately improving the care provided to women, their babies and families.

\section{Royal College of Midwives Annual Midwifery Awards}

Subjects: There are nine categories of awards which celebrate the range of work and achievement of midwives midwifery education, midwifery management or leadership, innovations in midwifery, Members' Champion award, promotion of normal birth, outstanding contribution to care of newborns, award for turning vision into reality, midwifery impact on child development, promoting effective midwifery in community settings and Student Vision award

Purpose: To recognize and celebrate innovation in midwifery practice, education and research

Eligibility: Applicants may be individuals or small groups but should meet the criteria of 1 of the 10 categories. Check the website for complete details: www.rcm.org.uk/college/ annual-midwifery-awards/

Level of Study: Postgraduate, Professional development, Research

Type: Award

Value: Varies (up to UK $£ 20,000$ in total)

Frequency: Annual

No. of awards offered: 82

Application Procedure: Applicants must apply in writing or email to the address given below. The application must be accompanied by a 500 -word description of the project. Shortlisted candidates will be asked to attend an interview

Closing Date: 1 November (check with website)

Funding: Commercial

Contributor: Several

No. of awards given last year: 12 awards in 12 categories plus a midwife award

No. of applicants last year: 82

\section{For further information contact:}

Gothic House, 3 The Green, Richmond, TW9 1PL, Surrey, United Kingdom

Email: mail@chamberdunn.co.uk

Contact: Chamberlain Dunn Associates

\section{Ruth Davies Research Bursary}

Subjects: Midwifery

Purpose: To promote and develop midwifery research and practice

Eligibility: Open to practicing midwives who are RCM members, who have basic knowledge, skills and understanding of the research process, have access to research support in their trust or Institutes of Higher Education and who have been in practice for 2 years or more

Level of Study: Doctorate, Graduate, Postdoctorate, Postgraduate, Predoctorate, Professional development, Research

Type: Bursary

Value: UK $£ 5,000$ per bursary

Length of Study: 1 year

Frequency: Annual

Country of Study: United Kingdom

No. of awards offered: 4 shortlisted 
Application Procedure: Applicants must submit a succinct curriculum vitae covering the previous 5 years, a research proposal of no more than 2,500 words and letters of support from both employers and academics who are familiar with the applicant's work

Closing Date: 30 July (check the website)

Funding: Commercial

Contributor: Bounty

No. of awards given last year: 3

No. of applicants last year: 4 shortlisted

For further information contact:

Tel: $\quad$ (44) 2073123463

Email: marlyn.gennace@rcm.org.uk

Contact: Mrs Marlyn Gennace, Ruth Davies Research

Bursary Administrator

\section{Royal College of Nursing Foundation}

20 Cavendish Square, W1G 0RN, London, United Kingdom

Tel: $\quad$ (44) 2076473645

Email: renfoundation@ren.org.uk

Website: www.rcnfoundation.org.uk

Contact: Ms Grants Officer Awards Officer

The RCN Foundation is an independent charity supporting nursing to improve the health and well-being of the public.

\section{Mary Seacole Leadership and Development Awards}

Subjects: Nursing, midwifery and health visiting including public health, health policy, and health education

Purpose: To provide funding for a project, or other educational/development activity that benefits the health needs of people from black and minority ethnic communities

Eligibility: Open to nurses, midwives and health visitors in United Kingdom

Level of Study: Doctorate, Graduate, Postdoctorate, Postgraduate, Predoctorate, Professional development, Research

Type: Award

Value: UK $£ 12,500$, Development award UK $£ 6,250$

Length of Study: Unrestricted
Frequency: Annual

Study Establishment: Unrestricted

Country of Study: United Kingdom

No. of awards offered: 16

Application Procedure: Applicants must send a stamped addressed envelope to the Royal College of Nursing (RCN) to obtain details and an application form

Closing Date: 1 May

Funding: Government

Contributor: Department of Health

No. of awards given last year: 6

No. of applicants last year: 16

For further information contact:

Email: governance.support@rcn.org.uk

\section{Royal College of Obstetricians and Gynaecologists (RCOG)}

27 Sussex Place, Regent's Park, NW1 4RG, London, United Kingdom

Tel: $\quad$ (44) 2077726200

Fax: (44) 2077230575

Email: mgoonewardene@rcog.org.uk

Website: www.rcog.org.uk

Contact: M Goonewardene, Awards Administrator

The Royal College of Obstetricians and Gynaecologists (RCOG) is dedicated to the encouragement of the study, and the advancement of science and practice of obstetrics and gynaecology.

\section{American Gyneocological Club/Gynaecological Visiting Society Fellowship}

Purpose: Through generous funding from the American Gynecological Club and the Gynaecological Visiting Society of Great Britain, the RCOG can offer up to $£ 1200$ to an individual to visit and gain knowledge from a specific centre offering new techniques of clinical management within O\&G Eligibility: This award is open to Trainees in the United Kingdom and Republic of Ireland and their equivalents in the United States of America in alternating years. For the current year, only applicants from the United Kingdom are eligible. Applicants may make a submission to travel from the United Kingdom to the United States of America

Level of Study: Postgraduate 
Type: Fellowship

Frequency: Annual

Country of Study: Any country

Application Procedure: Please ensure you read the guidance on submitting your application before entering any of the awards. current year Applications To apply, please send your application form (Word document) to the Awards Administrator awards@rcog.org.uk by midnight on Friday 31 May. Your application will be judged on the following criteria: Presentation and planning, Originality of elective, Evidence of student supervision and support, level of involvement and benefit of applicant

Closing Date: 31 May

Funding: Private

\section{For further information contact:}

Email: awards@rcog.org

\section{Bernhard Baron Travelling Fellowship}

Purpose: The Bernhard Baron Charitable Trust has generously endowed to the RCOG two travel scholarships in obstetrics and gynaecology for Fellows and Members of the College worth up to $£ 6000$ each

Eligibility: 1 . Travel must take place within 12 months of the award being made. 2 . The award may only be used for the purpose outlined in your original application. 3. A detailed report (maximum 1,000 words), including pictures if necessary, must be submitted to the RCOG Awards Administrator within eight weeks after the elective

Level of Study: Postdoctorate

Type: Fellowships

Value: up to $£ 6000$

Length of Study: 1 year

Frequency: Annual

Country of Study: Any country

Closing Date: 31 May

Funding: Foundation

\section{For further information contact:}

27 Sussex Place Regent's Park NW1 4RG, London, United Kingdom

Tel: (44) 2077726200

Fax: (44) 2077230575

Email: awards@rcog.org.uk

\section{Bruggeman Postgraduate Scholarship in Classics}

Purpose: Doctoral scholarships are awarded by the University Council, on the recommendation of the Senate, to candidates proceeding to a course of supervised doctoral study at this University. These scholarships are normally available only to students seeking to obtain their first doctoral qualification

Level of Study: Postgraduate

Type: Scholarship

Value: NZ \$25,000

Frequency: Annual

Country of Study: New Zealand

Closing Date: Applicants can apply anytime

Funding: Foundation

For further information contact:

Email: scholarships@otago.ac.nz

\section{Calcutta Eden Hospital Annual Prize}

Purpose: The Calcutta (Kolkata) Eden Hospital is notable because it is where the highly reputed Professor Green Armytage spent his professional career for 25 years at the turn of the 20th century. During his tenure, he designed 'uterine haemostatic forceps' which are still widely used around the world in caesarean sections

Eligibility: The prize is awarded for the best submission of an article that outlines your insight into any aspect of obstetrics and gynaecology undertaken during your training. Preference will be given to well-planned and presented applications

Level of Study: Postdoctorate

Type: Grant

Value: $£ 350$

Frequency: Annual

Country of Study: Any country

Closing Date: 31 May

Funding: Foundation

For further information contact:

Email: awards@rcog.org.uk

\section{Eden Travelling Fellowship in Obstetrics and Gynaecology}

Purpose: Generously endowed by the late Mr Thomas Watts Eden, this fellowship is awarded to a medical graduate (who graduated within the last two years) currently undertaking a research project. The winner can use the funds to visit any other department(s) within O\&G or a related discipline to gain additional knowledge and experience

Eligibility: This Fellowship is open to medical graduates (who graduated within the last 2 years) who are currently undertaking a research project. 1. Travel must take place within 12 months of the award being made in December. 
2. The award may only be used for the purpose outlined in your original application. 3. A detailed report (maximum 1,000 words), including pictures if necessary, must be submitted to the RCOG Awards Administrator within eight weeks after the elective. 4. Applicants must declare that their project is entirely their own work and whether they have applied for other prizes for the same project

Level of Study: Postdoctorate, professional development Type: Fellowship

Value: up to $£ 5,000$

Length of Study: 2 year

Frequency: Annual

Country of Study: Any country

Closing Date: 31 May

Funding: Foundation

\section{For further information contact:}

Email: awards@rcog.org.uk

\section{Edgar Gentilli Prize}

Purpose: Through the kind and generous bequest of the late $\mathrm{Mr}$ and Mrs Gilbert Edgar, the RCOG is delighted to offer this award of $£ 750$ plus $£ 250$ in book tokens to the candidate who submits the best piece of original work on the cause, nature, recognition and treatment of any form of cancer of the female genital tract

Eligibility: 1. The Edgar Gentilli Prize is open to both members and non-members of the RCOG. 2. Candidates for the prize should submit results of their research by way of an original manuscript, adequately referenced and written in a format comparable to that used for submission to a learned journal, or by means of a reprint of the published article. 3. A maximum of 2,000 words with a maximum of 10 references should be submitted. Applications that are over the word limit will be marked down

Level of Study: Graduate

Type: Prize

Frequency: Annual

Country of Study: Any country

Application Procedure: To apply, please send your application to the Awards Administrator awards@rcog.org.uk by midnight on Friday 31 May. Further procedure of the application is available on the below link. www.rcog.org. uk/en/careers-training/awards-grants-prizes/submitting-yourapplication/

Closing Date: 31 May

Funding: Private

\section{For further information contact:}

Email: awards@rcog.org.uk

\section{Elizabeth Garrett Anderson Hospital Charity Travelling Fellowship in Memory of Anne Boutwood}

Purpose: Through the generosity of The EGA Hospital Charity, we award a prize of $£ 5,000$ to one United Kingdom trainee in the field of obstetrics and gynaecology in memory of Miss Anne Boutwood FRCOG

Eligibility: 1 . Travel must take place within 12 months of the award being made. 2 . The award may only be used for the purpose outlined in your original application. 3. A detailed report (maximum 1,000 words), including pictures if necessary, must be submitted to the RCOG Awards Administrator within eight weeks after the elective

Level of Study: Postgraduate

Type: Fellowship

Value: $£ 5,000$

Frequency: Annual

Country of Study: Any country

Closing Date: 31 May

Funding: Foundation

\section{For further information contact:}

Email: awards@rcog.org.uk

\section{Endometriosis Millenium Fund}

Purpose: The RCOG is proud to support the Organising Committee of the World Congress of Endometriosis who, through a generous donation, have established the Endometriosis Millennium Fund

Eligibility: Applications are invited for the following: 1. To provide monies to fund a pilot project, clinical or laboratory based in the field of endometriosis, or to provide monies to fund an extension of an existing project researching endometriosis, or; 2. To provide a contribution towards a travelling fellowship to attend a recognised training centre, preferably overseas, to obtain surgical training in the management of cases of endometriosis, beyond the skills expected of core training

Level of Study: Postgraduate

Type: Funding support

Frequency: Annual

Country of Study: Any country

Application Procedure: To apply, please send your application form (Word document) to the Awards Administrator awards@rcog.org.uk by midnight on Friday 31 May. For further information, refer the weblink below. www.rcog. org.uk/en/careers-training/awards-grants-prizes/submitting-yourapplication/

Closing Date: 31 May

Funding: Private 


\section{For further information contact:}

Email: awards@rcog.org.uk

\section{Ethicon Foundation Fund Travelling Fellowship}

\section{Subjects: Surgery}

Purpose: The objective of the Ethicon Foundation Fund Travelling Fellowship, established through the generosity of Ethicon Limited, is to promote international goodwill in medicine and surgery by means of grants to assist the overseas travel of surgeons

Eligibility: 1. Applicants must be MRCS(Glasg) or FRCS (Glasg) and in a higher training post in the United Kingdom, or equivalent elsewhere in the world. 2. The proposed work experience, research or other study should be of clear benefit to the individual's training and to the NHS- or equivalent- on return. 3. Periods abroad should generally be between 1-12 months. 4. Awards will not be given for the sole purpose of attending meetings, or conferences to present papers or for undertaking a series of brief visits to multiple centres

Level of Study: Postgraduate

Type: Travel grant

Value: Up to UK $£ 900$

Frequency: Annual

Country of Study: Any country

No. of awards offered: 10

Application Procedure: Download and complete the application form and return the completed form to the address given. Make sure to include in your application: Your CV A signed letter of support from your current supervisor A signed letter from the centre you will be visiting confirming that you are welcome

Closing Date: 30 April

No. of awards given last year: 6

No. of applicants last year: 10

Additional Information: Travel must take place within

6 months of the award being made

\section{For further information contact:}

Royal College of Physicians and Surgeons of Glasgow, 232 - 242 St Vincent Street, G2 5RJ, Glasgow, United Kingdom

Tel: (44) 1412216072

Email: scholarships@rcpsg.ac.uk

\section{Ethicon Student Elective Award}

Purpose: The RCOG, with the kind and generous support of Ethicon, was pleased to offer up to $£ 500$ of funding towards approved student medical electives in obstetrics and gynaecology taking place between autumn current and upcoming year Eligibility: The successful applicant will have submitted well-planned and well-presented applications demonstrating clear objectives and offering detailed information about the project they wish to undertake. Students wishing to pursue a career in obstetrics and gynaecology and undertaking their elective in a subject associated with this specialty in a low-resource country were particularly encouraged to apply. Successful applicants are required to provide a report on their elective. They will also be invited to receive their certificate at an RCOG event. 1. Travel must take place within 12 months of the award being made. Retrospective applications will not be accepted. 2. The award may only be used for the purpose outlined in your original application. 3. A detailed report (maximum 1,000 words), including pictures if necessary, must be submitted to the RCOG Awards Administrator within eight weeks after the elective

Level of Study: Postgraduate

Type: Award

Value: Upto UK $£ 500$

Frequency: Annual

Country of Study: Any country

Application Procedure: To apply, please send your application form (Word document) to the Awards Administrator awards@rcog.org.uk by midnight on Friday 31 May. Application form is available on the below link. www.rcog.org.uk/ globalassets/documents/careers-and-training/awards-prizes/ 2019/ethicon-student-elective-application-form-2019.docx

Closing Date: 31 May

Funding: Private

\section{For further information contact:}

Email: awards@rcog.org.uk

\section{Florence and William Blair Bell Research Fellowship}

Purpose: The funding has been donated in order to stimulate and encourage research (clinical or laboratory based) in the field of O\&G. Clinicians are encouraged, with the use of funds, to acquire extra clinical or research skills to improve patient management or develop their postdoctoral research Eligibility: 1. If the application is for travel funding, travel must take place within 12 months of the award being made. 2 . The award may only be used for the purpose outlined in your original application. 3. A detailed report (maximum 1,000 words), including pictures if necessary, must be submitted to the RCOG Awards Administrator at the end of the grant period. 4. An undertaking must be given that the source of the grant will be acknowledged in any related publications 
Level of Study: Postgraduate

Type: Fellowship

Value: up to UK£5,000

Frequency: Annual

Country of Study: Any country

Closing Date: 31 May

Funding: Foundation

\section{For further information contact:}

Email: awards@rcog.org.uk

\section{Green-Armytage and Spackman Travelling Scholarship}

Purpose: Through the generosity of the late Mr V B GreenArmytage and of the late Colonel W C Spackman, Council is able to award a biennial travelling scholarship up to $£ 4,000$ to a Fellow or Member of the College

Eligibility: Applicants should have shown a special interest in some particular aspect of obstetrical or gynaecological practice. The donors' wishes are that the awards should be used for the purpose of visiting centres where similar work is being carried out. Your application will be judged on the following criteria: 1. Presentation well planned and presented.

2. Relevance of project to career development in $\mathrm{O} \& \mathrm{G}$.

3. Level of involvement. 4. References. 5. Value to the NHS/local community. 6. Value to personal development

Level of Study: Postgraduate

Type: Scholarship

Value: $£ 4,000$

Frequency: Annual

Country of Study: Any country

Application Procedure: Applicants must include information on qualifications, areas of interest and/or publications in a specified area, centres to be visited with confirmation from the head of that centre, estimated costs and the names of two referees

Closing Date: 24 May

Funding: Private

\section{For further information contact:}

Email: mgoonewardene@rcog.org.uk

\section{Herbert Erik Reiss Memorial Case History Prize}

Purpose: The prizes will be awarded to candidates who, in the opinion of the assessors, undertake the best presentation of a clinical case, including critical assessment and literature research, in a topic of obstetrics and gynaecology
Eligibility: Open to FY1 and FY2 doctors or Specialist Training Years 1 and 2 in the United Kingdom and the Republic of Ireland

Level of Study: Postgraduate

Value: First prize is UK $£ 400$ and second prize is UK $£ 200$

Frequency: Annual

Country of Study: Any country

No. of awards offered: 20

Application Procedure: A maximum of 1,500 words with maximum of 10 references should be submitted. Please include a statement of contribution to the project and indicate the name and address of the supervisor. Only one submission per candidate is permitted

Closing Date: 31 May

No. of awards given last year: 3

No. of applicants last year: 20

Additional Information: Please contact at mgoonewar dene@rcog.org.uk for further details

\section{For further information contact:}

Email: awards@rcog.org.uk

\section{John Lawson Prize}

Purpose: The prize will be awarded to a candidate who, in the opinion of the assessors, undertakes the best article on a topic of obstetrics or gynaecology derived from work carried out in Africa between the tropics of Capricorn and Cancer

Eligibility: Candidature is not restricted to fellows and members of the college

Value: UK $£ 150$

Frequency: Annual

Country of Study: Any country

No. of awards offered: 8

Application Procedure: The record of the work can be submitted by way of an original manuscript, adequately referenced and written in a format comparable to that used for submission to a learned journal, or by means of a reprint of a published article

Closing Date: 31 May

No. of awards given last year: 1

No. of applicants last year: 8

Additional Information: If joint authorship is involved then the candidate must identify his/her involvement in the publication

\section{For further information contact:}

Email: mgoonewardene@rcog.org.uk 


\section{Malcolm Black Travel Fellowship}

Purpose: The purpose of the fellowship is to enable a College Member of up to five years' standing or a Fellow at the time of application, to travel either to the British Isles or from the British Isles abroad, for a period of time to attend postgraduate training courses

Eligibility: RCOG Council reserves the right to withhold the granting of an award if, in its opinion, no work of sufficient merit is submitted. Applications that do not comply with the stipulations of the relevant award will not be accepted. Please note that all applications must be received electronically

Level of Study: Postgraduate

Type: Fellowship

Value: UK $£ 1,000$

Frequency: Every two years

Country of Study: Any country

Application Procedure: Please ensure you read the guidance on submitting your application before entering any of the awards. Travel must take place within 12 months of the award being made. The award may only be used for the purpose outlined in your original application. A detailed report (maximum 1,000 words), including pictures if necessary, must be submitted to the RCOG Awards Administrator within eight weeks after the elective. Your application will be judged on the following criteria: 1. Presentation well planned and presented. 2. Relevance of project to career development in O\&G. 3. Level of involvement. 4. References

Closing Date: 31 May

Funding: Private

\section{Overseas Fund}

Subjects: Obstetrics and gynaecology

Purpose: To allow individuals to travel to the United Kingdom for further training

Eligibility: Open to RCOG members or the equivalent, working overseas

Level of Study: Professional development

Type: Travel grant

Value: Up to UK $£ 2,500$

Frequency: Annual

Country of Study: Any country

No. of awards offered: 3

Application Procedure: Applicants must see the website Closing Date: 31 May

No. of awards given last year: 1

No. of applicants last year: 3

\section{For further information contact:}

Email: mgoonewardene@rcog.org.uk

\section{Peter Huntingford Memorial Prize}

Subjects: Obstetrics and Gynaecology

Purpose: The prize is for presenting the best case history, clinical audit or a report of a research project in any aspect of fertility control in which the applicant is directly involved

Eligibility: Open to doctors working in their foundation year or specialist training years 1 and/or 2 in the United Kingdom and the Republic of Ireland

Type: Grant

Value: First prize is UK $£ 150$ and second prize is UK $£ 75$

Frequency: Annual

Country of Study: Any country

No. of awards offered: 2

Application Procedure: A submission of no more than 1,500 words outlining the research with reference to publications (if any) is required. Please include a statement of the contribution to the project and indicate the name and address of the supervisor. Only one submission per candidate is permitted

Closing Date: 31 May

Contributor: British Pregnancy Advisory Service (BPAS)

No. of awards given last year: 1

No. of applicants last year: 2

\section{For further information contact:}

Email: mgoonewardene@rcog.org.uk

\section{Royal College of Obstetricians and Gynaecologists Edgar Research Fellowship}

Subjects: Obstetrics and gynaecology

Purpose: To encourage research, especially into chorion carcinoma or other forms of malignant disease

Eligibility: Open to candidates of high academic standing either in obstetrics and gynaecology, or related fields

Level of Study: Postgraduate

Type: Fellowship

Value: Up to a maximum of UK $£ 35,000$

Length of Study: Initially for 1 year's research but a further year's funding may be offered

Frequency: Annual

Country of Study: Any country

Application Procedure: Please contact the Research Administrator at the WellBeing address

Closing Date: First Monday in December

Additional Information: In making the award the Council of the College will bear in mind the original intention of the fellowship, which was to encourage research into chorion carcinoma or other forms of malignant disease. Where applications of equal merit are received, priority will be given to 
the project most closely related to this condition. Fellows are required to submit a report on the work carried out as soon as the tenure of the fellowship is completed

\section{For further information contact:}

WellBeing 27 Sussex Place Regent's Park, United Kingdom

\section{Tel: $\quad$ (44) 2077726338 \\ Fax: (44) 2077247725 \\ Email: mary.stanton@wellbeing.org.uk \\ Contact: Research Administrator}

\section{Royal College of Obstetricians and Gynaecologists Research Training Fellowships}

Subjects: Gynaecology and obstetrics

Purpose: To further the training of a young medical graduate in research techniques and methodology in a subject in a subject of direct or indirect relevance to obstetrics and gynaecology

Eligibility: Candidates will have had their basic training in obstetrics and gynaecology, preferably having passed their MRCOG. Candidates will be expected to enrol for a higher degree

Type: Fellowship

Value: Up to a maximum of three years salary

Length of Study: Up to 3 years

Frequency: Annual

Application Procedure: Enquiries about this award should be directed to The Research Administrator, WellBeing

Closing Date: First Friday in October

For further information contact:

WellBeing 27 Sussex Place Regent's Park, United Kingdom

Tel: $\quad$ (44) 2077726338

Fax: (44) 2077247725

Email: mary.stanton@wellbeing.org.uk

Contact: Research Administrator

\section{Royal College of Obstetricians and Gynaecologists WellBeing Grants}

Subjects: Obstetrics and gynaecology

Purpose: To fund research into all aspects of Obstetrics and Gynaecology with emphasis on increasing safety of childbirth for mother and baby and prevention of handicap

Eligibility: Open to specialists in any obstetrics and gynaecology inter-related field

Level of Study: Professional development, Research
Type: Grant

Value: Maximum of UK $£ 80,000$ over three years, with not more than UK $£ 45,000$ in the first year

Frequency: Annual

Application Procedure: Applicants must write for details

Funding: Private

For further information contact:

WellBeing 27 Sussex Place Regent's Park, United Kingdom

Tel: $\quad$ (44) 2077726338

Fax: (44) 2077247725

Email: mary.stanton@wellbeing.org.uk

Contact: Research Administrator

\section{Sims Black Travelling Proffesorship}

Purpose: The purpose of the Sims Black Travelling Professorship is to: Contribute to postgraduate education by presenting lectures, participating in seminars, group discussions and clinical demonstrations (if appropriate)

Eligibility: Check for the eligibility through the below link. www.rcog.org.uk/en/careers-training/awards-grants-prizes/ sims-black-travelling-professorship/

Level of Study: Postgraduate

Type: Professorship

Frequency: Annual

Country of Study: Any country

Closing Date: 1 March

Funding: Private

\section{For further information contact:}

Email: vbytel@rcog.org.uk

\section{Target Ovarian Cancer essay prize}

Purpose: The Target Ovarian Cancer essay prize is supported by The Royal College of Obstetricians and Gynaecologists. The prize is open to all undergraduate medical students across the United Kingdom. Its aim is to encourage students to read more widely on ovarian cancer, to think about some of the current issues and learn about recent research

Level of Study: Postgraduate

Type: Prize

Value: $£ 500$

Frequency: Annual

Country of Study: Any country

Closing Date: 30 June

Funding: Foundation 


\section{For further information contact:}

Email: essay@targetovariancancer.org.uk

\section{Tim Chard Chase History Prize}

Subjects: Obstetrics and gynaecology

Purpose: To award students showing the greatest understanding of a clinical problem in obstetrics and gynaecology

Level of Study: Professional development

Type: Prize

Value: 1 st prize UK $£ 500 ; 2$ nd prize UK $£ 200$

Frequency: Annual

Country of Study: United Kingdom, Northern Ireland and Republic of Ireland

Application Procedure: Applications should consist of one case history with discussion - max. of 1,500 words with 10 references

Closing Date: 15 February

Funding: Private

\section{For further information contact:}

Royal College of Obstetricians and Gynaecologists, 27 Sussex

Place, Regent's Park, United Kingdom

Tel: (44) 2077726263

Fax: (44) 2077726359

Email: rdeshmukh@rcog.org.uk

\section{William Blair Bell Memorial Lecture}

Purpose: The purpose of the lectureship is to allow a clinician or scientist who is at any stage of their career between award of an $\mathrm{MD} / \mathrm{PhD}$ and the completion of their second year as a Senior Lecturer or its equivalent (e.g. Clinician Scientist), at the time of application, to give a lecture describing research in any area pertaining to Women's Health at the RCOG Annual Academic Meeting

Eligibility: 1. Clinician or scientist between the award of their $\mathrm{MD} / \mathrm{PhD}$ thesis and completion of their second year as a Senior Lecturer or its equivalent. 2. Proposed lecture describes their personal research in any area pertaining to Women's Health

Level of Study: Postgraduate

Type: Grant

Frequency: Annual

Country of Study: Any country

Closing Date: 31 May

Funding: Foundation
For further information contact:

Email: awards@rcog.org.uk

\section{Women's Visiting Gynaecological Club Prize}

Purpose: Through the generosity of the Women's Visiting Gynaecological Club, the RCOG is able to offer $£ 500$ towards an overseas elective in obstetrics and gynaecology to a medical student in the United Kingdom or Republic of Ireland

Eligibility: 1. The winner of this prize will be a medical student who presents an application that best articulates their reasoning and objectives for wanting to complete an overseas elective in a certain region. 2 . The report submitted after this elective period is circulated to the members of the Women's Visiting Gynaecological Club

Level of Study: Postgraduate

Type: Prize

Value: $£ 500$

Frequency: Annual

Country of Study: Any country

Closing Date: 31 May

Funding: Foundation

For further information contact:

Email: awards@rcog.org.uk

\section{Royal College of Ophthalmologists}

18 Stephenson Way, Euston, NW1 2HD, London, United Kingdom

Tel: $\quad$ (44) 2079350702

Fax: (44) 2079359838

Email: training@rcophth.ac.uk

Website: www.rcophth.ac.uk

Contact: Vanda Fadda, Deputy Head of Education and Training

The college is responsible for promoting high standards of professional practice, setting curricula and conducting examinations and providing professional support and advice for ophthalmologists. The college runs an annual scientific congress and seminars for ophthalmologists and publishes a range of clinical guidelines. 


\section{Bayer Educational Grant Awards}

Subjects: Ophthalmology

Purpose: Supporting ophthalmologists to present work at educational meetings in the United Kingdom and overseas

Eligibility: Application from any grade of ophthalmologist working in the United Kingdom. Members and fellows of the Royal College of Ophthalmologists

Level of Study: Postgraduate

Type: Travel award

Value: Varies

Country of Study: United Kingdom

No. of awards offered: 37

Closing Date: April and October/November

Funding: Commercial

Contributor: Bayer HealthCare, Bayer plc

No. of awards given last year: 11

No. of applicants last year: 37

Additional Information: Please see the website for further

details www.rcophth.ac.uk

\section{For further information contact:}

Email: helen.sonderegger@rcophth.ac.uk

\section{Essay Prize for Foundation Doctors}

Purpose: Entries are now invited to the Essay Prize for Foundation Doctors on the essay "Discuss the impact of multi professional working on eye care"

Eligibility: 1. The competition is open to all those currently in a United Kingdom Foundation Programme. (F1, F2) at the time of submission, as well as those who have completed the United Kingdom Foundation Programme but have not yet achieved an OST1 post. 2. Entries are invited on the essay "Discuss the impact of multi professional working on eye care"

Level of Study: Postgraduate

Type: Grant

Frequency: Annual

Country of Study: Any country

Application Procedure: Essays of up to 1,500 words should be submitted to education@rcophth.ac.uk

Closing Date: 7 October

Funding: Private

\section{For further information contact:}

18 Stephenson Way, Kings Cross, NW1 2HD, London, United Kingdom

Email: education@rcophth.ac.uk

\section{Keeler Scholarship}

Purpose: To enable the scholar to study, research or acquire special skills, knowledge or experience at a suitable location in the United Kingdom or elsewhere for a minimum period of 6 months

Eligibility: Applicants must be Fellows, Members or Affiliates of the Royal College of Ophthalmologists, those Fellows, Members and Affiliates being in good standing. Potential applicants who have received substantial (usually meaning amounts greater than the value of the scholarship) funding for their project are not eligible for the Keeler Scholarship. The trustees will give special consideration to candidates intending to make a career in ophthalmology in the United Kingdom. Applicants may apply retrospectively but should not be more than 3 months into the fellowship for which they are applying for support by 10 February (application closing date)

Level of Study: Postgraduate

Type: Scholarship

Value: Upto UK $£ 30,000$

Length of Study: 2 years

Frequency: Annual

Country of Study: Any country

Application Procedure: 5 copies each of the application form duly completed and the candidate's curriculum vitae should be submitted

Closing Date: 10 February

Funding: Private

Contributor: Keeler Ltd

Additional Information: Funds will be paid to the Scholar two months before the start date of the project or fellowship

\section{For further information contact:}

The Royal College of Ophthalmologists Education and Training Department - Awards and Prizes, 18 Stephenson Way NW1 2HD, London, United Kingdom

Email: education@rcophth.ac.uk

\section{Patrick Trevor-Roper Undergraduate Award}

Subjects: Ophthalmology

Purpose: Applications are invited for the Patrick TrevorRoper Award, which is open to all undergraduate medical students from the United Kingdom and Ireland who have an interest in the specialty. The money may be used to fund electives in Ophthalmology, and may be spent on traveling or subsistence 
Eligibility: Medical Undergraduates

Level of Study: Postgraduate

Type: Award

Value: $£ 550$

Frequency: Annual

Country of Study: Any country

Application Procedure: Please post 4 hard copies of your application form and CV to: The Royal College of Ophthalmologists, Education and Training Department - Awards and Prizes, 18 Stephenson Way, NW1 2HD, London, United Kingdom

Closing Date: 31 May

Funding: Private

Additional Information: education@rcophth.ac.uk

\section{For further information contact:}

The Royal College of Ophthalmologists, Education and Training Department - Awards and Prizes, 18 Stephenson Way, Kings Cross, NW1 2HD, London, United Kingdom

Email: education@rcophth.ac.uk

\section{Royal College of Ophthalmologists- Bayer Research}

\section{Royal College of Ophthalmologists-Bayer Research Award}

Purpose: The Royal College of Ophthalmologists and Bayer have come together in a partnership to launch a grant to promote research in ophthalmology

Eligibility: Any Ophthalmic Specialist Trainee, Member or Fellow of The RCOphth with an interest in research

Level of Study: Postgraduate

Type: Award

Value: $£ 8,000$

Frequency: Annual

Country of Study: Any country

Closing Date: 30 March

Funding: Foundation

For further information contact:

Email: education@rcophth.ac.uk

\section{Royal College of Organists (RCO)}

PO Box 56357, SE16 7XL, London, United Kingdom
Tel: $\quad$ (44) 5600767208

Email: admin@rco.org.uk, andrew.mccrea@rco.org.uk

Website: www.rco.org.uk

Contact: Andrew McCrea, Director of Academic

Development

The Royal College of Organists (RCO) is membership based. It promotes the art of organ playing as choral directing, and provides an organization with a library, events and examinations to further that object.

\section{Royal College of Organists Scholarships and Awards}

Subjects: Organ playing

Purpose: To assist organists with professional playing

Eligibility: Open to members of the College. Only in exceptional circumstances will awards be made to non members. Membership is open to all upon payment of an annual subscription

Level of Study: Unrestricted

Type: Grant

Length of Study: 1 year, renewable

Frequency: Annual

Study Establishment: Varies

Country of Study: Any country

Application Procedure: Applicants must write for an application form

Closing Date: 17 February, 16 February

Funding: Private

Contributor: College trusts

For further information contact:

Email: andrew.parmley@rco.org.uk

\section{Royal College of Organists Various Open Award Bequests}

Subjects: Art and design

Purpose: To assist students who are training to become organists

Eligibility: School and students in undergraduate and postgraduate education who are members of the college

Level of Study: Postgraduate, Professional development

Type: Award

Value: Between UK $£ 100$ and UK $£ 400$ each

Frequency: Annual

Study Establishment: Various

Application Procedure: Write for an application form 
Closing Date: 18 April (check with website for updated details)

Funding: Private

For further information contact:

Email: admin@rco.org.uk

Contact: The Registrar

\section{Royal College of Physicians and Surgeons of Canada (RCPSC)}

Office of Fellowship Affairs 774 Echo Drive, Ottawa, ON K1S 5N8, Canada
Tel:
(1) 6137308177
Fax: (1) 6137308830
Email: awards@rcpsc.edu
Website: rcpsc.medical.org/
Contact: Dr James Hickey, FRCPC, Director

The Royal College of Physicians and Surgeons of Canada is a national organisation responsible for setting and maintaining the standards for postgraduate medical education, for the certification of specialist physicians and surgeons in Canada, and for promoting their continued education. The College benefits from the co-operation of its 30,000 members (Fellows), Canada's 16 faculties of medicine and national speciality societies.

\section{Canadian Research Awards for Specialty Residents (Medicine, Surgery)}

For further information contact:

Email:1locas@rcpsc.edu

\section{Royal College of Surgeons}

\section{Ethicon Travel Award}

Purpose: Ethicon Foundation Fund travel awards for overseas visits are awarded to fellows and members of the College who are in good standing

Eligibility: 1. The successful applicants will have submitted a well-articulated and well-planned application outlining the purpose and objectives of their trip. 2. It will provide detailed information about the work they would carry out during their placement to advance the practice and development of O\&G. 3 . The award may only be used for the purpose outlined in your original application. A detailed report (maximum 1,000 words), including pictures if necessary, must be submitted to the RCOG Awards Administrator within eight weeks after the elective. It supports the user by contributing to economy travel class upto the value $£ 1,000$

Level of Study: Graduate

Type: Award

Value: $£ 500$ payment will be awarded

Frequency: Annual

Country of Study: United Kingdom

Application Procedure: The successful applicant will be required to provide a report on their travelling fellowship

Closing Date: 14 March

Funding: Private

\section{For further information contact:}

The Royal College of Surgeons of United Kingdom, 35-43 Lincoln's Inn Fields, WC2A 3PE, London, United Kingdom

\section{Email: 1slater@rcseng.ac.uk}

Contact: Research Department

\section{Royal College of Surgeons of United Kingdom}

35-43 Lincoln's Inn Fields, WC2A 3PE, London, United Kingdom

Tel: $\quad$ (44) 2078696611

Fax: (44) 2078696644

Email: research@rcseng.ac.uk

Website: www.rcseng.ac.uk

Contact: Miss Bumbi Singh, Research Department

The Royal College of Surgeons of United Kingdom is an independent professional body committed to promoting and advancing the highest standards of surgical care for patients.

\section{Ethicon Foundation Fund}

Subjects: Surgery

Purpose: To promote international goodwill in surgery and to assist Fellows travelling abroad for research or training purposes 
Eligibility: Open to Fellows of the Royal College of Surgeons of United Kingdom. Applicants should be sufficiently advanced in their training to benefit from such an experience or be within 1 year of their appointment as a consultant. Fellows, Members or Affiliate Members of the RCOphth who are travelling abroad for research or training

Level of Study: Professional development

Type: Grant

Value: $£ 300-£ 1,500$

Length of Study: Varies

Frequency: Twice a year

Country of Study: Any country

Application Procedure: Applicants must send eight copies of the application form to the Research Department of the College and should include a letter of support from the head of department or consultant under whom the applicant is currently working and a letter of support from another independent referee. Application forms are available from The Research Department at the main address

Closing Date: 18 December (TBC)

\section{Royal Geographical Society (with the Institute of British Geographers)}

\author{
1 Kensington Gore, SW7 2AR, London, United Kingdom \\ Tel: $\quad$ (44) 2075913000 \\ Fax: (44) 2075913001 \\ Email: grants@rgs.org \\ Website: www.rgs.org/grants \\ Contact: Juliette Scull, Grants Officer
}

The Royal Geographical Society (with the Institute of British Geographers) is the United Kingdom's learned society for geography and geographers and a professional body. It supports and promotes many aspects of geography including geographical research, education and teaching, field training and small expeditions, the public understanding and popularization of geography and the provision of geographical information.

\section{0th International Geographical Congress Award}

Subjects: Geography

Purpose: To assist with the cost of attending an international geographical conference

Eligibility: Applicants must be United Kingdom/European Union nationals and must currently be employed by a United
Kingdom Institute of Higher Education. Preference will be given to applicants within 6 years of completion of $\mathrm{Ph}$ D. Attendance at AAG, CAG, or the RGS-IBG Annual Conference is not eligible for support from this award

Level of Study: Research

Type: Award

Value: Up to $£ 750$

Length of Study: Unspecified

Frequency: Annual

Country of Study: Any country

No. of awards offered: 12

Application Procedure: Applicants must download the guidelines and application form from the website www.rgs. org/grants or contact the grants officer

Closing Date: 30 September

No. of awards given last year: 5

No. of applicants last year: 12

\section{For further information contact:}

Email: grants@rgs.org

\section{Environment and Sustainability Research Grants}

Purpose: To support researchers investigating some of the bigger issues in environmental sustainability

Eligibility: Please see www.rgs.org/grants

Type: Grant

Value: $£ 10,000$

Frequency: Annual

Country of Study: Any country

Application Procedure: Please see www.vgs.org

Closing Date: 22 February

No. of awards given last year: 4

For further information contact:

Email: NCER_Communications@epa.gov

\section{Geographical Club Award}

Subjects: Geography

Purpose: To support a postgraduate student (Masters or $\mathrm{PhD}$ ) undertaking geographical fieldwork

Eligibility: Applicants must be United Kingdom/European Union nationals and must currently be registered for a Masters or PhD at a United Kingdom Institute of Higher Education. Students who receive full funding from a Research Council or comparable levels of support from other sources with support for fieldwork/data collection are not eligible to apply

Level of Study: Doctorate, Postgraduate

Type: Award 
Value: $£ 1,000$

Frequency: Annual

Country of Study: United Kingdom or elsewhere

No. of awards offered: 20

Application Procedure: Applicants must download the application guidelines from the website www.rgs.org/grants or contact the grants officer. There is no application form

Closing Date: 23 November

No. of awards given last year: 2

No. of applicants last year: 20

For further information contact:

Email: grants@rgs.org

\section{Ray Y. Gildea Jr Award}

Purpose: To support innovation in teaching and learning in higher and secondary education

Eligibility: The project should focus on innovation in teaching and learning of geography in higher education/college and/or secondary school level; including curriculum development, teaching and learning methods, and applications of new technology. 1. Projects that seek to research, develop and/or pilot innovations are eligible. 2. Outcomes should directly benefit students of geography. 3. Applicants must be currently employed in the higher education (college) sector and/or secondary school level, either in the United Kingdom or the United States of America and actively teaching students. 4. Applicants must be United Kingdom or United States of America nationals Type: Grant

Frequency: Annual

Country of Study: Any country

Application Procedure: Please see www.rgs.org/grants

Closing Date: 30 November

No. of awards given last year: 1

For further information contact:

Email: grants@rgs.org

\section{Walters Kundert Fellowship}

Purpose: To support field research within arctic or high mountain environments

Eligibility: Please see www.rgs.org/grants

Type: Grant

Value: $£ 10,000$

Frequency: Annual

Country of Study: Any country

Closing Date: 23 November
For further information contact:

Email: grants@rgs.org

\section{Royal Holloway, University of London}

Egham, TW20 0EX, Surrey, United Kingdom

Tel: (44) 1784443399

Fax: (44) 1784471381

Email: liaison-office@rhul.ac.uk

Website: www.rhul.ac.uk

Contact: Ms Claire Collingwood, Schools \& International Liaison Officer

All departments of Royal Holloway, University of London seek to provide taught programmes that reflect the latest developments and are responsive to the needs of students and society, together with research and scholarship, which contribute to the advancement of knowledge and the enhancement of public policy, wealth creation and the quality of life.

\section{Royal Holloway, University of London MBA Programme}

Application Procedure: Applicants must complete an application form

Closing Date: 30 June

\section{For further information contact:}

School of Management Royal Holloway University of London, United Kingdom

Tel: $\quad$ (44) 1784443780

Fax: (44) 1784439854

Email: school-management@rhul.ac.uk

Contact: MBA Admissions Officer

\section{Royal Horticultural Society (RHS)}

80 Vincent Square, SW1P 2PE, London, United Kingdom

Tel: $\quad$ (44) 8452605000

Fax: (44) 1483212382

Email: bursaries@rhs.org.uk

Website: www.rhs.org.uk/courses/bursaries

Contact: Secretary of RHS Bursaries Committee 
The Royal Horticultural Society (RHS) is a membership charity holding a Royal Charter for horticulture. The Society promotes the science, art and practice of horticulture in all its branches through a wide range of educational, research and advisory activities. It also maintains some major gardens, shows and the internationally renowned Lindley Library.

\section{Blaxall Valentine Bursary Fund}

Purpose: To help finance worldwide plant collecting in natural habitats and study expeditions that will provide real benefits to horticulture

Eligibility: Open to applicants worldwide, but preference is given to United Kingdom citizens. Financial sponsorship will be available to both professional and amateur horticulturists and consideration for an award is not restricted to RHS members. Proposals may be made by individuals or group of individuals

Level of Study: Unrestricted

Type: Bursary

Value: Funds are limited. High-cost projects are expected to receive supplementary finance from other sources, including personal contributions

Frequency: Annual

Country of Study: Any country

Application Procedure: Applicants must complete an application form downloaded from the RHS website www.rhs.org. $\mathrm{uk} /$ bursaries

Closing Date: 15 December, 31 March, 30 June, or 30 September (check the website for updated details)

Funding: Private

No. of awards given last year: 17

Additional Information: Please contact at bursaries@rhs. org.uk for applying and deadline

\section{For further information contact:}

Email: bursaries@rhs.org.uk

\section{Royal Horticultural Society Financial Awards}

\section{Subjects: Horticulture}

Purpose: To help finance horticulture-related projects and to further the interests of horticultural education along with horticultural work experience

Eligibility: Submissions are welcomed from applicants worldwide, but preference is given to United Kingdom and Commonwealth citizens. Applicants should preferably be within the age bracket of 20 and 35 years and satisfy the Society that their health enables them to undertake the project proposed. Financial sponsorship will be available to both professional and amateur horticulturists, and consideration for an award is not restricted to RHS members. Proposals may be made by individuals or groups

Level of Study: Unrestricted

Type: Bursary

Value: Funds are limited. High-cost projects are expected to receive supplementary finance from other sources, including personal contributions

Frequency: Annual

Country of Study: Any country

Application Procedure: Applicants must complete an application form, available on request. Candidates may be called for interview

Closing Date: 24 December, 31 March, 30 June or 30 September

Funding: Private

No. of awards given last year: 6

Additional Information: Recipients must submit a brief factual report within 3 months of completion, along with an outline of achievements or difficulties, including any unusual problems, e.g. medical or political, and an account of expenses

\section{For further information contact:}

Email: bursaries@rhs.org.uk

\section{Royal Horticulture Society Bursary Scheme}

Subjects: The Royal Horticultural Society (RHS) is a membership charity holding a Royal Charter for Horticulture. The Society promotes the science, art and practice of horticulture in all its branches through a wide range of educational, research and advisory activities. It also maintains some major gardens, shows and the internationally renowned Lindley Library

Purpose: To broaden skills, increase knowledge and enhance career opportunities related to Horticulture

Eligibility: United Kingdom citizens may apply for projects worldwide. Others may only apply for projects based in the United Kingdom

Level of Study: Unrestricted

Type: Bursary

Value: Funds are limited. High-cost projects are expected to receive supplementary finance from other sources

Frequency: Annual

Country of Study: United Kingdom

Application Procedure: Applicants must complete an application form downloadable from the RHS website www.rhs. org.uk/bursarie. For further updates on the closing date, please check with the website 
Closing Date: 15 December, 31 March, 30 June, or 30 September

Funding: Private

Additional Information: For further enquires on the bursary

scheme, Please email bursanes@rhs.org.uk

\section{For further information contact:}

RHS Garden, Wisley, Woking, GU23 6QB, Surrey, United Kingdom

Email: bursanes@rhs.org.uk

Contact: Ms Rowena Wilson, Secretary

\section{Royal Institution of Chartered Surveyors Education Trust}

Royal Institution of Chartered Surveyors, RICS, Parliament Square, SW1P 3AD, London, United Kingdom

Tel: $\quad$ (44) 2476868555

Fax: (44) 2073343811

Email: contactrics@rics.org

Website: www.rics-educationtrust.org

The Royal Institution of Chartered Surveyors (RICS) is the professional institution for the surveying profession.

\section{Royal Institution of Chartered Surveyors Education Trust Award}

Subjects: The theory and practice of surveying in any of its disciplines including general practice, quantity surveying, building surveying, rural practice, planning and development, land surveying or minerals surveying

Eligibility: Open to chartered surveyors and others carrying out research studies in relevant subjects

Level of Study: Unrestricted

Type: Research grant

Value: Up to UK $£ 7,500$

Country of Study: Any country

No. of awards offered: 40

Application Procedure: Applicants must complete an application form, available to download online at www.ricseducationtrust.org

Closing Date: 30 September or 28 February

Funding: Commercial

Contributor: RICS

No. of awards given last year: 20

No. of applicants last year: 40
For further information contact:

Email: contactrics@rics.org

\section{Royal Irish Academy}

19 Dawson Street, Dublin 2, Ireland

Tel: $\quad$ (353) 16762570

Fax: (353) 16762346

Email: admin@ria.ie

Website: www.ria.ie

Contact: Ms Laura Mahoney, Assistant Executive Secretary

The Royal Irish Academy is the senior institution in Ireland for both the sciences and humanities. It publishes a number of journals and monographs. It is Ireland's national representative in a large number of international unions, and through its national committees runs conferences, lectures and workshops. It also manages a number of long-term research projects. The Academy participates in the Royal Society European Science Exchange Programmes in pure and applied science, in the British Academy European Exchange Programmes in the humanities, and in the Austrian, Hungarian, or Polish academy exchange schemes in science and the humanities. Small grants for work in all disciplines are available annually from the Academy's own funds.

\section{Royal Irish Academy Senior Visiting Fellowships}

Subjects: Scientific research other than in social sciences, dentistry and theoretical and clinical medicine

Purpose: To enable a new scientific research technique or development to be introduced into the Republic of Ireland

Eligibility: Open to senior researchers from member countries of the Organisation for Economic Co-operation and Development (OECD) only

Level of Study: Postdoctorate, Professional development Type: Fellowship

Value: Varies

Frequency: Annual Country of Study: Other

Application Procedure: Applicants must complete an application form

Closing Date: 15 October

Funding: Government

No. of awards given last year: 10 
Additional Information: Senior Visiting Fellowships are made on behalf of the Irish government

For further information contact:

Email: grants@ria.ie

\section{Royal Literary Fund RLF}

3 Johnson's Court, EC4A 3EA, London, United Kingdom

Tel: $\quad$ (44) 2073537160

Email: rlitfund@btconnect.com

Website: www.rlf.org.uk

Contact: Steve Cook, Fellowship Officer

The RLF has been continuously helping authors since it was set up in 1970. It is funded by requests and donations from writers who help other writers. Its committee members came from all walks of literary life and include novelists, biographers, poets, publishers, lawyers and agents.

\section{Royal Literary Fund Grant}

Subjects: Literature, authorship

Purpose: To support prolific writers suffering financial hardship Eligibility: Open to applicants who have published several works for a general readership and are suffering financial hardship (books stemming from a parallel career as an academic or practitioner are not eligible)

Level of Study: Professional development

Type: Grant

Value: Funds are decided by the committee case by case

Length of Study: 1 year

Frequency: Annual

Country of Study: United Kingdom

Application Procedure: Contact the RLF General Secretary

Closing Date: There is no deadline

Contributor: RLF

No. of awards given last year: 12

\section{For further information contact:}

The Royal Literary Fund, 3 Johnson's Court, Off Fleet Street, United Kingdom

Tel: $\quad$ (44) 2073537159

Email: egunnrlf@globalnet.co.uk

Contact: Eileen Gunn, General Secretary

\section{Royal Melbourne Institute of Technology University}

Info Corner - Office for Prospective Students, GPO Box 2476, Melbourne, VIC 3001, Australia

Tel: $\quad$ (61) 399252260

Fax: (61) 399253070

Email: study@rmit.edu.au

Website: www.rmit.edu.au

RMIT University is one of Australia's original and leading educational institutions producing some of Australia's most employable graduates. RMIT has an international reputation for excellence in work-relevant education professional and vocational education, high quality research, and engagement with the needs of industry and community.

\section{Interior Design-Masters of Arts by Research}

Subjects: Sculpture, film, theatre, journalism, visual arts, interior design, and architecture

Purpose: To offer a space within which candidates develop and contribute to the knowledge and possibilities of interior design

Eligibility: Open to the candidates of any country who have a First Degree of RMIT with at least a credit average in the final undergraduate year or a deemed equivalent by RMIT to a First Degree of RMIT with at least a credit average in the final undergraduate year or evidence of experience

Level of Study: Postgraduate

Length of Study: 2 years full-time (Masters) and 4 years parttime $(\mathrm{PhD})$

Application Procedure: Check website for further details Closing Date: 31 October

Funding: Government

Contributor: Commonwealth Government

Additional Information: Please check the website for more details

\section{For further information contact:}

Tel: $\quad$ (233) 399252819

Email: suzie.attiwill@rmit.edu.au

Contact: Ms Suzie Attiwill, Research Coordinator 


\section{Royal Melbourne Institute of Technology PhD Scholarship in the School of Electrical and Computer Engineering}

Eligibility: To be eligible for this scholarship you must: be enroled in a higher degree by research (HDR) at the RMIT School of Electrical and Computer Engineering; be a top ranking student using the RMIT University Scholarships Ranking Model; awarded an APA or RMIT PhD Scholarship and/or an RTS place; be aligned to one of the school's areas of strategic focus; not previously have held any Electrical and Computer Engineering (ECE) scholarship over the past 3 years (or more); demonstrate excellent academic results and research capability

Type: Scholarship

Value: $\$ 12,000$

Frequency: Annual

Country of Study: Australia

Application Procedure: International applicants are expected to apply for the RMIT International PhD Scholarship. If successful, the school may supplement the scholarship stipend

Additional Information: Preference will be given to $\mathrm{PhD}$ students but high ranking Masters by Research students may also be eligible for the top-up scholarship

\section{For further information contact:}

Tel:

$$
\text { (61) } 399253174
$$

Email: elecengresearch@rmit.edu.au

Contact: Laurie Clinton, Research Administrator

\section{Royal Over-Seas League ARTS}

Over-Seas House, Park Place, St James's Street, SW1A 1LR, London, United Kingdom

Tel: $\quad$ (44) 2074080214 ext 219

Fax: $\quad$ (44) 2074996738

Email: info@rosl.org.uk

Website: www.rosl.org.uk

Contact: Mandy Murphy, Administrative Assistant

The principal aim of the ROSL (Royal Over-Seas League) ARTS is to provide performance and exhibition opportunities for prize-winning artists and musicians early in their careers, bringing their work to the attention of the professional arts community, the media and the general public.

\section{Royal Over-Seas League Annual Music Competition}

Subjects: Musical performance, in four solo classes such as strings (including the harp and guitar), wind and percussion, keyboard, singers and to ensemble classes

Purpose: To support and promote young Commonwealth musicians

Eligibility: Open to the citizens of the United Kingdom and Commonwealth, including former Commonwealth countries, for instrumentalists and singers up to and including the age of 30 as at the date of the final concert

Level of Study: Professional development

Type: Competition

Value: Over UK $£ 60,000$ in prizes, including a UK $£ 10,000$ gold medal and first prize and UK $£ 10,000$ for ensembles

Frequency: Annual

Country of Study: Any country

No. of awards offered: 500

Application Procedure: Applicants must see the website: www.roslarts.org.uk

Closing Date: 15 January

Funding: Commercial, Private, Trusts, Individuals

No. of awards given last year: 19

No. of applicants last year: 500

For further information contact:

Email: head-conmus@uwa.edu.au

\section{Royal Over-Seas League Travel Scholarship}

Subjects: ROSL will consider work in any medium Purpose: To support and promote young United Kingdom and Commonwealth artists

Eligibility: Open to citizens of Commonwealth, including the United Kingdom, and former Commonwealth countries, who are up to 35 years of age, on year of application

Level of Study: Graduate, Postgraduate, Professional development, Unrestricted

Value: UK $£ 3,000$

Frequency: Annual

Country of Study: United Kingdom or Commonwealth No. of awards offered: 450

Application Procedure: Applicants must see the website: www.roslarts.co.uk

Closing Date: 31 March

Funding: Commercial, Private, Trusts

No. of awards given last year: 5

No. of applicants last year: 450 
Additional Information: Each artist may be represented by one recent work only, any medium. Works must not exceed $152 \mathrm{~cm}$ in their largest dimension, inclusive of frame

\section{For further information contact:}

Email: Membership@rosl.org.uk

\section{Royal Society}

6-9 Carlton House Terrace, SW1Y 5AG, London, United Kingdom

Tel: $\quad$ (44) 2074512500

Fax: (44) 2079302170

Email: info@royalsoc.ac.uk

Website: www.royalsoc.ac.uk

Contact: Research Appointments Officer

The Royal Society is the independent scientific academy of the United Kingdom dedicated to promoting excellence in science. It plays an influential role in national and international science policy and supports developments in science engineering and technology in a wide range of ways.

\section{Global Challenges Research Fund Challenge-led Grants (GCRF)}

Purpose: Generate excellent and novel research on global challenges directly and primarily relevant to developing countries that cuts across multiple thematic areas covered by the Sustainable Development Goals (SDGs).' Strengthen research capacity in developing countries through collaboration, sharing of knowledge and skills, and exchange of staff between research groups in the United Kingdom and their partners in developing countries

Eligibility: 1. Your proposed research must address two or more GCRF thematic areas. The proposal must ultimately benefit the economic development and welfare of developing countries (i.e. be compliant with the ODA guidelines). 2. Your proposal must fall within the remit of the United Kingdom academies and must be interdisciplinary. The consortia must consist of one United Kingdom research group and two research groups from developing countries

Level of Study: Graduate

Type: Grants, work-study (not just grants)

Country of Study: Any country
Application Procedure: Application should be submitted through the Royal Society's grants and awards management system (Flexi-Grant ${ }^{\circledR}$ ). and weblink is grants.royalsociety. org/. Shortlisted proposals will be subject to high quality independent peer review, and once complete these proposals will then be discussed at a Panel meeting

Closing Date: 11 September

Funding: Private

\section{For further information contact:}

Email: ChallengeGrants@royalsociety.org

\section{Olga Kennard Research Fellowship Scheme}

Subjects: Crystallography or structural molecular biology Eligibility: Open to citizens of the European Union, Norway, Israel and Switzerland. Applicants must have at least 3 years of postdoctoral experience and be aged between 26-40 years Level of Study: Postdoctorate

Type: Fellowship

Value: Salary with London allowance where appropriate, together with annual research expenses, travel expenses and a contribution to baggage costs for overseas applicants

Length of Study: 5 years

Study Establishment: Appropriate university departments Country of Study: United Kingdom

Application Procedure: Applications can only be submitted online on the Royal Society's E-gap system. For further information on this scheme or the E-gap process, submit an enquiry to ukgrants@royalsoc.ac.uk

Closing Date: There is no fixed deadline

Additional Information: Further information is available on the website

\section{For further information contact:}

Email: ukresearch.appointments@royalsoc.ac.uk

\section{Royal Society South East Asia Rainforest Research Project - Travel Grants}

Subjects: Research into rainforests

Eligibility: Open to scientists and nationals of European Union countries and South East Asia countries who are $\mathrm{PhD}$ or MSc students

Level of Study: Postgraduate

Type: Travel grant

Value: Economy air fare plus two weeks subsistence for European scientists travelling to South East Asia or three 
months subsistence for South East Asian scientists travelling to Europe

Length of Study: Varies

Country of Study: Other

Application Procedure: Applicants must apply for information, available on request from Programme Research Coordinator, Dr Stephen Sutton (email sutton@hh.edi.co.uk) or Dr A J Davis

Additional Information: Further information available on request

\section{For further information contact:}

Department of Zoology, University of Cambridge, United Kingdom \& Danum Valley Field Centre, PO Box 60282, United Kingdom

Fax: (44) 89884046

Email: ajdavis@pc.jaring.my

Contact: Dr A J Davis, Royal Society Senior Scientist at Danum Valley

\section{Sir Henry Dale Fellowships}

Purpose: Leading the research programme

Eligibility: You can apply for a Small Grant if you're a humanities or social science researcher with a compelling research vision and you want to do one or more of the following: 1. build your professional network. 2. develop a new research agenda. 3. increase the impact of your work

Level of Study: Postdoctorate, Research

Type: Research grant

Value: Value includes a basic salary, fellowship supplements. research and personal removal expenses. Check with website

Frequency: Every 5 years

Country of Study: Any country

Closing Date: 2 April

Funding: Private

For further information contact:

Tel: $\quad$ (44) 2074512500

Email: grants@royalsociety.org

\section{Royal Society of Chemistry}

Burlington House Piccadilly, W1J 0BA, London, United Kingdom
Tel:
(44) 2074378656
Fax: $\quad$ (44) 2074378883
Email:_langers@rsc.org

\section{Website: www.rsc.org \\ Contact: Mr S S Langer}

The Royal Society of Chemistry is the learned society for chemistry and the professional body for chemists in the United Kingdom with 46,000 members worldwide. The Society is a major publisher of chemical information, supports the teaching of chemistry at all levels, organizes hundreds of chemical meetings a year and is a leader in communicating science to the public. It is now the United Kingdom National Adhering Organization (NAO) to the International Union of Pure and Applied Chemistry (IUPAC).

\section{Royal Society of Chemistry Journals Grants for International Authors}

Subjects: Chemistry

Purpose: To allow international authors to visit other countries in order to collaborate in research, exchange research ideas and results, and to give or receive special expertise and training Eligibility: Open to anyone with a recent publication in any of the Society's journals. Those from the United Kingdom or Republic of Ireland are excluded

Level of Study: Professional development

Type: Grant

Value: Up to $£ 2,500$ cover travel and subsistence (but not research related costs) and are available

Length of Study: Normally 1-3 months

Country of Study: Any country

No. of awards offered: 107

Application Procedure: Candidates must apply for application forms, together with full details, from the International Affairs Officer

Closing Date: 1 January, 1 April, 1 July or 1 October

No. of awards given last year: 83

No. of applicants last year: 107

Additional Information: Please see the website for further details www.rsc.org/ScienceAndTechnology/Funding/Travel Grants/InternationalAuthors.asp

For further information contact:

Email:1langers@rsc.org

\section{Royal Society of Edinburgh}

22-26 George Street, EH2 2PQ, Edinburgh, United Kingdom

Tel: $\quad$ (44) 1312405000

Fax: (44) 1312405024 
Email: afraser@royalsoced.org.uk

Website: www.royalsoced.org.uk

Contact: Anne Fraser, Research Awards Manager

The Royal Society of Edinburgh is Scotland's national academy of science and letters. It offers research and enterprise awards to candidates based in Scotland.

\section{Royal Society of Edinburgh Personal Research Fellowships}

Subjects: All science and social science subjects

Purpose: To provide outstanding researchers, who have the potential to become leaders in their chosen field, with the opportunity to build an independent research career

Eligibility: Open to persons of all nationalities who have 2 to 6 years postdoctoral experience. They must also show that they have the capacity for innovative research and the potential to become leaders in their field

Level of Study: Doctorate

Value: Salary and research support costs for 5 years

Length of Study: 5 years

Frequency: Annual

Study Establishment: Any Higher Education Institution in Scotland

Country of Study: Scotland

No. of awards offered: 53

Application Procedure: Applicants must complete an application form, available on the RSE website. Applicants should negotiate directly with their host institution

Closing Date: 16 February

Contributor: Scottish Government, BP and Caledonian Research Fund

No. of awards given last year: 3

No. of applicants last year: 53

Additional Information: Successful applicants will be allocated a funding provider (BP, CRF or Scottish Government) according to their subject area. BP funding is available every 2nd year and is for candidates working in areas of interest to BP. CRF funding is for candidates in the biomedical sciences. Fellows are expected to devote their full time to research and are not allowed to hold any other paid appointments without the express permission of Council. Website: www.royalsoced.org. uk/649_RSEPersonalResearchFellowships.html

\section{For further information contact:}

Email: schooloffice-ls@dundee.ac.uk

\section{Royal Society of Medicine (RSM)}

1 Wimpole Street, W1G 0AE, London, United Kingdom

Tel:

(44) 2072903846

Fax: (44) 2072902989

Email: awards@rsm.dc.uk

Website: www.rsm.ac.uk/awards

Contact: Awards Manager, Alademic Department

The Royal Society of Medicine (RSM) provides academic services and club facilities for its members as well as publishing a monthly journal and an annual bulletin, and providing over 400 educational conferences and meetings per year. The RSM offers around 60 awards and prizes each year. The majority for medical doctors in training covering the majority of specialities in medicine and surgery.

\section{Adrian Tanner Prize}

Subjects: Clinical case reports should be submitted to reflect the multidisciplinary nature of the care for surgical patients

Purpose: To encourage surgical trainees submit the best clinical case reports

Eligibility: Open to all surgeons in training

Value: UK $£ 250$

Frequency: Annual

Study Establishment: Royal Society of Medicine-Surgery section

Country of Study: United Kingdom

No. of awards offered: 50

Application Procedure: Applicants should download an application form from www.rsm.ac.uk/awards

Closing Date: 28 March

No. of awards given last year: 1

No. of applicants last year: 50

For further information contact:

Email: surgery@rsm.ac.uk

\section{Alan Emery Prize}

Subjects: Genetics

Purpose: To reward the best published research article in Medical Genetics in the past 2 years

Eligibility: Open to candidates in an accredited training or research post in the United Kingdom 
Type: Prize

Value: $£ 500$ or $£ 300$ or 1 year membership of Royal Society of Medicine

Frequency: Annual

No. of awards offered: 7

Application Procedure: Candidates must submit full copy of the article, curriculum vitae or covering letter explaining the significance of the publication

Closing Date: 5 March(check with website)

No. of awards given last year: 1

No. of applicants last year: 7

For further information contact:

Email: genetics@rsm.ac.uk

\section{Cardiology Section Presidents Prize}

Subjects: Cardiology

Purpose: To reward original work for specialist registrar in cardiology

Eligibility: Open to cardiology trainees who have received all or part of their training at recognized centres of excellence in the United Kingdom. The subject of the presentation should represent original work

Level of Study: Research

Type: Prize

Value: Commemoration medal and $£ 1,000$ (First prize); $£ 500$ (Second prize)

Frequency: Annual

Study Establishment: Recognized centres of excellence in United Kingdom

Country of Study: United Kingdom

Application Procedure: Candidates should submit an abstract of no more than 200 words

Closing Date: 8 May

Contributor: Cardiology Section Funds

No. of awards given last year: 2

For further information contact:

Cardiology Section, Royal Society of Medicine, 1 Wimpole Street, United Kingdom

Email: cardiology@rsm.ac.uk

\section{Catastrophes \& Conflict Forum Medical Student Essay Prize}

Subjects: Medicine and surgery
Eligibility: Open to candidates who are enroled full-time at a United Kingdom medical school

Level of Study: Postgraduate

Type: Prize

Value: $£ 250$ plus encouragement and advice on submitting the essay for publication in the JRSM

Frequency: Annual

Study Establishment: Royal Society of Medicine

Country of Study: United Kingdom

No. of awards offered: 9

Application Procedure: Candidates should submit an essay no longer than 1,500 words, emailed in Word format

Closing Date: 1 March

No. of awards given last year: 2

No. of applicants last year: 9

For further information contact:

Email: catastrophes@rsm.ac.uk

\section{Clinical Forensic and Legal Medicine Section Poster Competition}

\section{Subjects: Clinical studies}

Purpose: To present a case or a poster in clinical studies

Eligibility: Undergraduate students who have been working as part of courses leading to primary qualifications such as Legal Medicine Special Study Modules and electives for MBBS

Value: $£ 250$

Frequency: Annual

Application Procedure: Please visit the website www.rsm. ac.uk/academ/awards/index for application form details

Closing Date: 15 December

For further information contact:

Email: forensic@rsm.ac.uk

\section{Clinical Immunology \& Allergy President's Prize}

Subjects: Immunology or allergy

Eligibility: Open to training grade doctors and young scientists (not above Specialist Registrar, Grade B Clinical Scientist or equivalent grade) with an immunological or allergy component of their clinical research

Level of Study: Research

Type: Prize

Value: $£ 300$ (First prize); two prizes of $£ 100$ (Second prize)

Frequency: Annual 
Country of Study: United Kingdom

No. of awards offered: 10

Application Procedure: Check website for further details

Closing Date: Check the website

No. of awards given last year: 3

No. of applicants last year: 10

For further information contact:

Email: immunology@rsm.ac.uk

\section{Clinical Neurosciences Gordon Holmes Prize}

Subjects: Clinical neurosciences

Purpose: To award a research prize in clinical neurosciences Eligibility: Trainees in neurosciences, including neurology, neurosurgery, neurophysiology, neuropathology or neuroradiology

Type: Prize

Value: $£ 300$

Frequency: Every 2 years

Application Procedure: Please check the website www.rsm. ac.uk/prizes-awards/trainees.aspx

Closing Date: Check the website

\section{For further information contact:}

Email: cns@rsm.ac.uk

\section{Clinical Neurosciences President's Prize}

Subjects: Neurology

Purpose: To encourage clinical case presentation

Eligibility: Open to trainees in neurosciences, including neurology, neurosurgery, neurophysiology, neuropathology, or neuroradiology

Type: Prize

Length of Study: $£ 300$

Frequency: Every 2 years

Application Procedure: Applicants must submit one A4 page (up to 500 words) summary of research carried out. Those considered to be the best will be asked to give a 15 minute presentation

Closing Date: Check with website

For further information contact:

Email: cns@rsm.ac.uk

\section{Coloproctology John of Arderne Medal}

Subjects: Coloproctology

Purpose: To award the presenter of the best paper presented at the short papers meeting of the section of coloproctology. Applicants have to submit an abstract for presentation at the meeting

Eligibility: Open to applicants of any nationality

Level of Study: Professional development

Type: Award

Value: Approx. UK $£ 600$

Frequency: Annual

Study Establishment: Varies

Country of Study: Any country

No. of awards offered: $14-20$

Application Procedure: Further details are available from the RSM administrator

Closing Date: September and November (check with website)

Funding: Private

No. of awards given last year: 1

No. of applicants last year: $14-20$

For further information contact:

Email: coloproctology@rsm.ac.uk

\section{Dermatology Clinicopathological Meetings}

Subjects: Clinicopathology

Eligibility: Trainee Dermatologists

Type: Prize

Value: $£ 150$

Frequency: Annual

Country of Study: United Kingdom

No. of awards offered: 32

Closing Date: Check the website

Contributor: Royal Society of Medicine

No. of awards given last year: 1

No. of applicants last year: 32

Additional Information: For more details, please refer the website: www.dermpath.com/news-events/calendar/pra ctical-symposium-sharpen-your-dermatology-clinicopathologicand-business

For further information contact:

Email: dermatology@rsm.ac.uk 


\section{Epidemiology \& Public Health Young Epidemiologists Prize}

Subjects: Epidemiology and public health

Purpose: To reward outstanding papers

Eligibility: Any medical/non-medical epidemiologist or pub-

lic health practitioner under the age of 40 years

Level of Study: Unrestricted

Type: Award

Value: $£ 250$

Frequency: Annual

Country of Study: United Kingdom

No. of awards offered: 9

Application Procedure: Download the application form from website

Closing Date: 27 November (check with website)

No. of awards given last year: 1

No. of applicants last year: 9

For further information contact:

Email: epidemiology@rsm.ac.uk

\section{General Practice with Primary Healthcare John Fry Prize}

Subjects: Primary healthcare

Purpose: To award best examples of practice-based research involving members of the primary health and social community, demonstrating and promoting effective team work

Eligibility: Open to candidates currently working in primary healthcare in the United Kingdom excluding members of the RSM section of GP Council

Level of Study: Unrestricted

Type: Prize

Value: $£ 300$

Frequency: Annual

Country of Study: United Kingdom

No. of awards offered: 4

Application Procedure: Application form must be completed in all respects

Closing Date: 27 March

Funding: Private

Contributor: John Fry

No. of awards given last year: 1

No. of applicants last year: 4

For further information contact:

RSM, 1 Wimpole Street, United Kingdom
Email: $\quad$ gp@rsm.ac.uk

Contact: Gemma Lamb

\section{Laryngology \& Rhinology Travel and Equipment Grants}

Subjects: Laryngology and rhinology

Purpose: To assist with the cost of travel to overseas centres

Eligibility: Open to senior registrars or consultants of not more than 2 years standing, who must be members of the section of laryngology and rhinology of the RSM

Level of Study: Postdoctorate

Type: Scholarship

Value: UK $£ 1,000$

Frequency: Annual

Country of Study: Any country

No. of awards offered: 25

Application Procedure: Applicants must submit a paper to the RSM section of laryngology and rhinology. Further details are available from the RSM administrator

Closing Date: 15 April

Funding: Commercial

Contributor: Karl Storz Endoscopy Limited

No. of awards given last year: 1

No. of applicants last year: 25

Additional Information: The recipient will be required to submit a brief report on the visit within 3 months of his or her return

For further information contact:

Email: laryngology@rsm.ac.uk

\section{Military Medicine Colt Foundation Research Prize}

Purpose: To recognize the best abstract by a serving military medical officer

Eligibility: Open to serving military officers in a training grade in general practice, a hospital or other speciality and are fellows of the RSM

Level of Study: Postgraduate

Type: Prize

Value: $£ 200$ (1st prize) and $£ 100$ each (2nd prize)

Frequency: Annual

Study Establishment: Royal Society of Medicine

Country of Study: United Kingdom

No. of awards offered: 15 
Application Procedure: Candidates should email the abstracts. The abstracts will be shortlisted by the panel and judged

Closing Date: 6 November

Funding: Trusts

Contributor: Colt Foundation

No. of awards given last year: 1

No. of applicants last year: 15

For further information contact:

Email: united.services@rsm.ac.uk

\section{Nephrology Section Rosemarie Baillod Clinical Award}

Eligibility: All doctors in training in nephrology and renal medicine at any grade

Type: Research award

Value: $£ 200$

Frequency: Annual

Country of Study: United Kingdom

Application Procedure: Please visit website for further details

Closing Date: Check the website

For further information contact:

Email: nephrology@rsm.ac.uk

\section{Occupational Medicine Section Malcolm Harrington Prize}

Subjects: Occupational medicine

Purpose: To award the work that is most likely to advance the study of occupational medicine in its broadest sense

Eligibility: Open to occupational physician in training or within an year of achieving specialist accreditation

Type: Prize

Value: $£ 250$

Frequency: Annual

No. of awards offered: 9

Application Procedure: Candidates should submit an abstract of their own work (no longer than 200 words)

Closing Date: 9 March (check the website)

Funding: Private

Contributor: Professor Harrington

No. of awards given last year: 1

No. of applicants last year: 9

\section{For further information contact:}

Email: occupational@rsm.ac.uk

\section{Oncology Section Sylvia Lawler Prize}

Subjects: Oncology

Purpose: To encourage scientists and clinicians in training to present the best scientific paper and best clinical paper on oncology

Eligibility: All scientists and clinicians in training

Level of Study: Postgraduate

Type: Grant

Value: Two prizes of $£ 500$ to oral presenters and one prize of $£ 50$ voucher to poster presenter

Frequency: Annual

Study Establishment: Royal Society of Medicine

Country of Study: United Kingdom

No. of awards offered: 50

Application Procedure: Applicants should download an application form from the website www.rsm.ac.uk/prizesawards/trainees.aspx, and submit the same via email to surgery@rsm.ac.uk

Closing Date: 19 April

No. of awards given last year: 1

No. of applicants last year: 50

For further information contact:

Email: oncology@rsm.ac.uk

\section{Ophthalmology Section Travelling Fellowships}

Subjects: Ophthalmology

Purpose: To enable British ophthalmologists to travel abroad with the intention of furthering the study or advancement of ophthalmology, or to enable foreign ophthalmologists to visit the United Kingdom for the same purpose

Eligibility: Open to ophthalmologists in the British Isles of any nationality who have not attained an official consultant appointment, nor undertaken professional clinical work or equivalent responsibility for any substantial period before or during the execution of original work

Level of Study: Professional development

Type: Fellowship

Value: UK $£ 500-1,000$

Frequency: Every 2 years

Study Establishment: Varies

Country of Study: Any country

No. of awards offered: 6

Application Procedure: Applicants must apply to the academic administrator at RSM

Closing Date: 1 May

No. of awards given last year: 4

No. of applicants last year: 6 
For further information contact:

Email: ophthalmology@rsm.ac.uk

\section{Orthopaedics Section President's Prize Papers}

Purpose: To encourage research in the area of Orthopaedics Eligibility: Open to all orthopaedic trainees

Level of Study: Postgraduate

Type: Prize

Value: Clinical paper prize - 1st prize of $£ 300$ and 2nd prize of $£ 200$

Frequency: Annual

Study Establishment: Royal Society of Medicine

Country of Study: United Kingdom

No. of awards offered: 10

Application Procedure: Candidates should submit abstracts no longer than 200 words. The abstracts will be judged by a panel of experts, shortlisted and asked to be presented at a meeting

Closing Date: 5 April

No. of awards given last year: 1

No. of applicants last year: 10

For further information contact:

Email: orthopaedics@rsm.ac.uk

\section{Otology Section Norman Gamble Grant}

Subjects: Otology

Purpose: To support specific research projects

Eligibility: British citizens, both lay and medical

Level of Study: Unrestricted

Type: Prize

Value: UK $£ 100$

Frequency: Annual

Country of Study: Any country

No. of awards offered: 4

Application Procedure: Further details are available from the RSM administrator

Closing Date: 9 December (check the website)

Funding: Private

No. of awards given last year: 1

No. of applicants last year: 4

For further information contact:

Email: otology@rsm.ac.uk

\section{Paediatrics \& Child Health Section Trainees Tim David Prize}

Subjects: Paediatrics
Purpose: To encourage research in the area of Paediatrics \& Child Health

Eligibility: Open to paediatric trainees

Level of Study: Postgraduate, Foundation programme

Type: Prize

Value: First prize $£ 150,1$ year's subscription to the RSM (worth up to £200) and membership of the Council of the Section of Paediatrics and Child Health for 1 year. There will also be a second prize of $£ 100$

Frequency: Annual

No. of awards offered: 12

Application Procedure: Candidates should submit abstracts Closing Date: 1 April

Contributor: Paediatrics \& Child Health Section, RSM

No. of awards given last year: 2

No. of applicants last year: 12

For further information contact:

Email: paediatrics@rsm.ac.uk

\section{Palliative Care Section MSc/MA research prize}

Eligibility: All students either currently studying, or within 18 months of completion, of MSc or MA in Palliative Medicine or an allied discipline, are eligible to apply

Level of Study: Postgraduate, Foundation programme

Type: Prize

Value: 1 st prize of $£ 250,2$ nd prize of $£ 100$, and 3rd prize of $£ 50$

Frequency: Annual

Closing Date: 17 September

Contributor: Palliative Care Section

For further information contact:

Email: palliative@rsm.ac.uk

\section{Psychiatry Section Mental Health Foundation Research Prize}

Subjects: Psychiatry

Purpose: To award an outstanding published paper

Eligibility: Open to candidates practising medicine in the United Kingdom or the Republic of Ireland who are in training at any grade from senior house officer to senior registrar or equivalent. Applicants need not be members of RSM

Type: Prize

Value: UK $£ 750$ (1st prize); UK $£ 100$ (2nd prize)

Frequency: Annual

Country of Study: United Kingdom

No. of awards offered: 1 
Application Procedure: Full copy of the published article, curriculum vitae and covering letter explaining in their own words the significance of the publication to be submitted to the section of psychiatry

Closing Date: Early January (check the website)

Funding: Private

No. of applicants last year: 1

For further information contact:

Email: psychiatry@rsm.ac.uk

\section{Surgery Section Norman Tanner Prize and Glaxo Travelling Fellowship}

Subjects: Oncology

Purpose: To encourage clinical registrars submit the best clinical paper

Eligibility: Open to all trainee oncologists

Value: $£ 250$ plus the Norman Tanner Medal. Runner up $£ 250$ Glaxo Travelling Fellowship

Frequency: Annual

Study Establishment: Royal Society of Medicine

Country of Study: United Kingdom

No. of awards offered: 30

Application Procedure: Applicants are requested to contact the Section Coordinator at oncology@rsm.ac.uk

Closing Date: 1 September

No. of awards given last year: 12

No. of applicants last year: 30

For further information contact:

Email: surgery@rsm.ac.uk

\section{Trainees' Committee John Glyn Trainees' Prize}

Purpose: The prize was established to promote best practise through high quality audit

Eligibility: Trainees from any hospital or primary care specialty

Level of Study: Graduate, Postgraduate, Research, Foundation programme

Type: Prize

Value: $£ 300$

Frequency: Annual

No. of awards offered: 40

Closing Date: 12 April(check with website)

Contributor: Royal Society of Medicine

No. of awards given last year: 1

No. of applicants last year: 40
For further information contact:

Email: trainees@rsm.ac.uk

\section{Urology Professor Geoffrey D Chisholm CBE Communication Prize}

Subjects: Urology

Purpose: To reward the best abstract at the Short Papers Prize Meeting

Eligibility: Open to members of the Urology section

Type: Travel award

Value: Fully funded RSM travelling fellowship to the Urology Section's overseas winter scientific meeting in the next academic session

No. of awards offered: 30

Closing Date: 8 March

No. of awards given last year: 3

No. of applicants last year: 30

For further information contact:

Email: urology@rsm.ac.uk

\section{Urology Section Professor John Blandy Essay Prize for Medical Students}

Subjects: Urology

Purpose: To enable the holder to enhance his or her knowledge and experience by visiting an overseas unit

Eligibility: Medical students

Type: Fellowship

Value: A bursary of $£ 1,000$ and an RSM award certificate

Frequency: Annual

Closing Date: 8 March

Additional Information: Candidates must be available on the May 16th for presentation of their short paper to be eligible for this prize

For further information contact:

Email: urology@rsm.ac.uk

\section{Urology Section Winter short papers prize (Clinical Uro-Radiological meeting)}

Subjects: Urology

Purpose: To reward the best clinicopathological short paper

Eligibility: Urological and radiological trainees 
Type: Prize

Value: Fully funded RSM travelling fellowship to the Urology Section's overseas winter scientific meeting in the next academic session. Runner up prizes of a bursary towards the RSM overseas winter scientific meeting in the next academic session

Frequency: Annual

Closing Date: Check the website

For further information contact:

Email: urology@rsm.ac.uk

\section{Venous Forum Spring Meeting Prizes}

Purpose: To recognize the best original paper by a non-consultant

Eligibility: Open to non-consultants

Level of Study: Postgraduate

Type: Prize

Value: $£ 250$ (1st prize); $£ 200$ (2nd prize); $£ 150$ (3rd prize); and $£ 200$ (Poster prize)

Frequency: Annual

Study Establishment: Royal Society of Medicine

Country of Study: United Kingdom

No. of awards offered: 20

Application Procedure: Candidates should email abstracts. Shortlisted candidates will be invited to present their papers

Closing Date: 13 March

No. of awards given last year: 1

No. of applicants last year: 20

For further information contact:

Email: venous@rsm.ac.uk

\section{Royal Scottish Academy (RSA)}

The Mound, EH2 2EL, Edinburgh, United Kingdom

Tel: $\quad$ (44) 1312256671

Fax: (44) 1312206016

Email: info@royalscottishacademy.org

Website: www.royalscottishacademy.org

Contact: Secretary

Founded in 1826, the RSA, Scotland's foremost body of artists, has promoted the works of leading contemporary painters, sculptors, printmakers and architects. It also gives practical and financial help to young artists through scholarships as well as the annual Student's Exhibition.

\section{The Barns-Graham Travel Award}

Subjects: Painting in any medium

Purpose: To provide a travel and research opportunity for graduating and postgraduate students

Eligibility: Entrants must be painters, printmakers or sculptors, entrants must either be graduating in the current academic year or currently studying at postgraduate level at one of the following art schools in Scotland - Aberdeen, Dundee, Edinburgh, Glasgow, and Moray

Level of Study: Postgraduate

Type: Scholarship

Value: $£ 2,000$

Length of Study: 3-6 months

Frequency: Annual

Study Establishment: Any of the main art colleges

Country of Study: Scotland

Application Procedure: Applications forms and regulations will be available to download at the end of February

Closing Date: 12 June

Funding: Private

Contributor: The Alastair Salvesen Trust

No. of awards given last year: 1

Additional Information: Please see the website for further details

For further information contact:

Email: opportunities@royalscottishacademy.org

\section{The Royal Scottish Academy John Kinross Scholarships to Florence}

Subjects: Art and Architecture

Purpose: for final year and postgraduate artists and architects to spend a period of 6 to 12 weeks in Florence to research and develop their practice

Eligibility: Art: Applications are invited from students in their Honours or post-graduate years of study at one of the following; art schools in Scotland (Aberdeen, Dundee, Edinburgh, Glasgow, and UHI). Architecture: Applicants must be RIBA Part 2 students in their final year, or currently attending a Masters programme,; at one of the six Scottish Schools of Architecture

Level of Study: Postgraduate, Undergraduate

Type: Scholarship

Value: UK $£ 2,000$

Length of Study: 6-12 weeks 
Frequency: Annual

Country of Study: Italy

Application Procedure: Digital submissions accepted only, please see the opportunities section of our website for more details

Closing Date: 24 March

Funding: Private

Contributor: The Kinross Scholarship Fund, which is administered by the RSA

No. of awards given last year: 10

\section{For further information contact:}

www.royalscottishacademy.org/artist-opportunities/

Email: opportunities@royalscottishacademy.org

\section{The Royal Scottish Academy William Littlejohn Award for Excellence and Innovation in Water- Based Media}

Subjects: Painting, sculpture, architecture and printmaking Purpose: To provide young professional artists who are Scottish or have studied in Scotland, with a period for personal development and the exploration of new directions

Eligibility: Entrants must be working in water-based media (any pigment mixed with water), entrants must be born or have been resident in Scotland for at least 3 years, in the case of students applying, entrants must either be graduating in current year or studying at postgraduate level at one of the following art schools in Scotland (Aberdeen, Dundee, Edinburgh, Glasgow, and Moray)

Level of Study: Postgraduate

Type: Residency

Value: UK $£ 2,000$

Frequency: Annual

Study Establishment: Hospitalfield House, Arbroath

Country of Study: Scotland

Application Procedure: Applicants must contact the RSA

Closing Date: 12 June

Funding: Private

Contributor: The Bequest Fund administered by the RSA

\section{For further information contact:}

Email: opportunities@royalscottishacademy.org

\section{Royal Town Planning Institute (RTPI)}

41 Botolph Lane, EC3R 8DL, London, United Kingdom

Tel: $\quad$ (44) 2079299494

Fax: $\quad$ (44) 2079299490

Email: judy.woollett@rtpi.org.uk

Website: www.rtpi.org.uk/

The Royal Town Planning Institute (RTPI) was founded in 1914 and is a registered charity. Its aim is to advance the science and art of town planning in all its aspects, including local, regional and national planning for the benefit of the public. The Institute is primarily concerned with maintaining high standards of competence and conduct within the profession, promoting the role of planning within the country's social, economic and political structures, and presenting the profession's views on current planning issues.

\section{George Pepler International Award}

Subjects: Town and country planning or some particular aspect of planning theory and practice

Purpose: To enable young people of any nationality to visit another country for a short period to study. The George Pepler International Award is a bursary granted biennially to a person in their first ten years of post-qualification experience wishing to undertake a short period of study (3-4 weeks) on a particular aspect of spatial planning

Eligibility: Open to persons under 30 years of age of any nationality. Candidature must have the age limit of upto 30 years

Level of Study: Professional development, Research

Type: Fees to performers

Value: Up to UK $£ 1,500$

Length of Study: Short-term travel outside the United Kingdom for United Kingdom residents or for visits to the United Kingdom for applicants from abroad

Frequency: Every 2 years

Country of Study: Any country

No. of awards offered: 20

Application Procedure: Applicants must submit a statement showing the nature of the study visit proposed, together with an itinerary. Application forms are available on request from the RTPI

Closing Date: 31 March 
Funding: Private

Contributor: Trust fund

No. of awards given last year: 1

No. of applicants last year: 20

Additional Information: At the conclusion of the visit the recipient must submit a report. Please see the website for further details www.rtpi.org.uk/events/awards/george-peplerinternational-award/

For further information contact:

Email: judy.woollett@rtpi.org.uk

\section{Rural Health Information Hub}

\section{National Board for Certified Counselors Minority Fellowship Program for Mental Health Counselors}

Purpose: The purpose of the program is to ensure that the behavioral health needs of all Americans are met, regardless of language or culture, thereby reducing health disparities Eligibility: Eligible applicants are United States citizens or permanent residents that are currently enrolled and in good standing in an accredited graduate level counseling program. Please check the website link for further details, www. ruralhealthinfo.org/funding/4510

Level of Study: Graduate

Type: Programme grant

Value: US $\$ 10,000$, plus travel expenses to participate in other program-related training

Frequency: Annual

Country of Study: Any country

Closing Date: 15 December

Funding: Private

Additional Information: For doctoral degree-level students: US\$20,000, plus travel expenses to participate in other program-related training. www.nbccf.org/programs/scholar ships/fellows

\section{For further information contact:}

School of Medicine and Health Sciences, Suite E231, 1301 N. Columbia Road, Stop 9037, Grand Forks, ND 582029037, United States of America

Email: info@ruralhealthinfo.org

\section{Rural Maternity Care Research}

Suite 530-1501 West Broadway, Vancouver, BC V6J 4Z6, Canada
Tel:
(1) 6047421796
Fax:
(1) 6047421798
Email:1eslie@ruralmatresearch.net
Website: www.ruralmatresearch.net

Rural Maternity Care Research is a team of academic and community based researchers interested in rural maternity care. They believe their diversity of expertise, backgrounds and interests enhance their ability to comprehensively investigate the complexity of challenges and opportunities for rural maternity care in British Columbia.

\section{Rural Maternity Care Doctoral Student Fellowship}

Subjects: Maternity care

Purpose: To enable a motivated Doctoral student researcher to join the interdisciplinary team investigating rural maternity care in British Columbia

Eligibility: Open to citizens or permanent residents of Canada who are registered in a Doctoral programme in Canada

Level of Study: Doctorate

Type: Fellowship

Value: Up to $\mathrm{C} \$ 45,000$ (benefits included)

Length of Study: 18 months

Frequency: Annual

Country of Study: Canada

Application Procedure: Applicants must include the following documents in the application: cover letter, transcripts, curriculum vitae, contact information of 3 research referees and sample of the candidates writing preferably from an article published in a referred journal

Closing Date: 18 August

Additional Information: The Fellow will be provided with office space in Vancouver, as well as access to and use of internet, printers and telephone and fax lines. Candidates from all academic disciplines are invited to apply. Candidates who may be completing coursework for their PhD programme, will be expected to contribute sufficient time to the RM-NET to develop a research focus area 


\section{For further information contact:}

Email: clin2@cw.bc.ca

Contact: Cynthia Lin Hsieh

\section{Ryerson University}

\section{Autism Scholars Award}

Purpose: With the support of the Ministry of Training, Colleges and Universities, a scholar awards program in autism has been established to ensure that Ontario attracts and retains pre-eminent scholars. The community of autism scholars fostered by this awards program will excel, according to internationally accepted standards of scientific excellence, in the creation of new knowledge concerning child autism, and its translation into improved health for children, more effective services and products for children with autism, and increase the province's capacity in diagnosis and assessment of autism and a strengthened treatment system

Eligibility: 1. a Canadian citizen or a permanent resident of Canada at the time of the application deadline (31 January). 2. registered as a full-time student in a master's or doctoral program at an Ontario university at the beginning of the award period (fall), and remain registered as a full-time student throughout the term of the award. 3. A master's student remains eligible until the end of the sixth term of full-time study. 4. A doctoral student remains eligible until the end of the 15th term of full-time study. 5. During the year an Autism Scholars Award is held, the recipient is precluded from holding any other award that offers financial support of more than $\$ 20,000$ for that same year (subject to the university's own policies)

Level of Study: Graduate

Type: Award

Value: $\$ 20,000$

Frequency: Annual

Country of Study: Any country

Closing Date: 31 January

Funding: International office

\section{For further information contact:}

Email: SeniorDirectorQA@cou.on.ca

\section{Ravi Ravindran Outstanding Doctoral Thesis Award}

Purpose: The C. Ravi Ravindran Outstanding Doctoral Thesis Award was established in 2008 (the 60th year of the creation of Ryerson as an educational institution) by his family in recognition of his long and distinguished industrial and academic career. He was the first winner of the Ryerson-Sahota Faculty Research Award, Trustee of ASM International, and the first Ryerson faculty member elected as Fellow, and later President of the Canadian Academy of Engineering

Eligibility: 1. Registration as a graduate studies student in a program of study leading to a PhD. 2. One student may be nominated by a program director from each $\mathrm{PhD}$ program. 3. A nominated student must have applied to graduate at the upcoming fall graduation convocation ceremonies or have already graduated at the spring graduation convocation ceremonies

Level of Study: Postgraduate

Type: Award

Value: $\$ 1,000$

Length of Study: 1 year

Frequency: Annual

Country of Study: Any country

Closing Date: 22 August

Funding: Foundation

\section{For further information contact:}

Email: grdadmit@ryerson.ca

\section{Canada's Distinguished Dissertation Awards}

Purpose: The CAGS/ProQuest Distinguished Dissertation Awards recognize Canadian doctoral dissertations that make unusually significant and original contributions to their academic field. They were established in 1994 and are presented annually

Eligibility: 1. A dissertation in any discipline in engineering, medical sciences and natural sciences completed and accepted by the Graduate School. 2. A dissertation in any discipline in the fine arts, humanities and social sciences completed and accepted by the Graduate School between 1 January and 31 December

Level of Study: Graduate

Type: Award

Value: $\$ 1,500$

Frequency: Annual

Country of Study: Any country

Closing Date: 25 February

Funding: International office

\section{For further information contact:}

Email: natasha.mills@ryerson.ca 


\section{Doctoral Completion Award}

Purpose: Funding amount is determined on a year-to-year basis and is a one-time-only award

Eligibility: 1. Satisfactory progress reports. 2. Comprehensive examination process. 3. Dissertation research proposal. 4. Those students who have a very high probability (ie. $90 \%$ ) to complete in their 4th year

Level of Study: Graduate

Type: Award

Value: Up to $\$ 10,000$

Frequency: Annual

Country of Study: Any country

Closing Date: 19 November

Funding: International office

\section{Edward S. Rogers Sr. Graduate Student Fellowships}

Subjects: The fellowships are available annually to recognize the accomplishments of master's and doctoral level students in the Communication \& Culture program who have demonstrated outstanding academic accomplishments in the communications field

Purpose: The Edward S. Rogers Sr. Graduate School Fellowship, first awarded in 2001, was established by Ted and Loretta Rogers to honour the contributions of Edward S. Rogers Sr. to the Canadian communications industry

Eligibility: All Canadian PhD students in the Communication \& Culture program

Level of Study: Graduate

Type: Fellowship

Value: $\$ 20,000$

Frequency: Annual

Country of Study: Any country

Closing Date: no deadline

Funding: Foundation

\section{For further information contact:}

Email: grdadmit@ryerson.ca

\section{Fulbright Canada Scholarship}

Purpose: The mandate of Fulbright Canada is to enhance mutual understanding between the people of Canada and the United States of America by providing support to outstanding graduate students, faculty, professionals, and independent researchers. These individuals conduct research, lecture, or enroll in formal academic programs in the other country. In doing so, Fulbright Canada aims to grow intellectual capacity, increase productivity, and assist in the shaping of future leaders in both countries

Eligibility: 1. Be a Canadian citizen (Permanent residence is not sufficient). 2. Hold a Bachelor's degree prior to the proposed start date of the grant. 3. Be proficient in English. 4. Be in compliance with all J. William Fulbright Foreign Scholarship Board (FFSB) guidelines. 5. Be in compliance with all governmental regulations regarding visas, immigration, travel and residence

Level of Study: Graduate

Type: Scholarship

Value: $\$ 15,000$

Frequency: Annual

Country of Study: Any country

Closing Date: 15 November

Funding: International office

For further information contact:

Email: grdadmit@ryerson.ca

\section{Governor General Gold Medal}

Purpose: The Governor General Gold Medal (GGGM), Ryerson University's most prestigious academic award, is awarded annually to the graduate student who achieves the highest academic standing in a graduate degree program

Eligibility: All master's and doctoral program students, who are in their first Master's or Doctoral program respectively, are eligible for this award. The student must have completed his/her program within the normal time frame (as deemed by the Yeates School of Graduate Studies)

Level of Study: Graduate

Type: Grant

Value: no nominal value

Frequency: Annual

Country of Study: Any country

Closing Date: 20 August

Funding: International office

For further information contact:

Email: natasha.mills@ryerson.ca

\section{Graduate Student Stipend}

Purpose: A graduate student stipend provides financial support to a graduate student while completing their graduate studies. Normally the stipend is paid from the research funding of a faculty supervisor. Stipends are not payment for employment

Level of Study: Graduate 
Type: Stipendiary

Value: Dollar amounts vary by program and/or discipline

Frequency: Annual

Country of Study: Any country

Closing Date: no deadline

Funding: International office

\section{For further information contact:}

Email: grdadmit@ryerson.ca

\section{John Charles Polanyi Prizes}

Purpose: In honour of the achievement of John Charles Polanyi, recipient of the 1986 Nobel Prize in Chemistry, the Government of the Province of Ontario has established a fund to provide annually up to five (5) prizes to outstanding researchers in the early stages of their careers who are continuing to postdoctoral studies or have recently started a faculty appointment at an Ontario university. The John Charles Polanyi Prizes are available in the areas broadly defined as Physics, Chemistry, Physiology or Medicine, Literature and Economic Science

Eligibility: 1. Normally resident in Ontario and has completed or is near completion of doctoral studies in any recognized university in the world, or has completed or is nearing completion of doctoral studies in an Ontario university. 2. Has received the doctoral degree between 1 September and 30 April, or if the doctoral degree has not yet been awarded, will have completed all the requirements for the doctoral degree by 30 April. Applicants holding faculty appointments within these time limits may apply. 3 . The prizes are awarded to assist the recipients in their research and professional development. 4 . The prizes may be held along with any other financial support or research funds received by the winners. 5 . It is hoped that the prizes will be conferred by September. No prize will be awarded without the successful applicant having completed all requirements for the doctoral degree

Level of Study: Graduate

Type: Grant

Value: $\$ 20,000$

Frequency: Annual

Country of Study: Any country

Closing Date: 1 December

Funding: International office

\section{For further information contact:}

Email: natasha.mills@ryerson.ca

\section{Sandbox student grant program}

Purpose: The DMZ Sandbox Student Grant Program (also known as the "Grant Program") will financially support and provide eligible Ryerson led startups with the crucial grant funding and mentorship they need

Eligibility: The Sandbox Student Grant Program is open to Ryerson students registered in a; full-time academic program or a recent graduates (up to eight months after date of; graduation) from a full-time academic program who meet the following eligibility. requirements

Level of Study: Postgraduate

Type: Grant

Value: up to $\$ 15,000$

Length of Study: 4 year

Frequency: Annual

Country of Study: Any country

Closing Date: 17 February

Funding: International office

\section{For further information contact:}

Email: sandbox@ryerson.ca

\section{Senior Women Academic Administrators of Canada Awards}

Purpose: The Senior Women Academic Administrators of Canada (SWAAC), external link organization was founded in 1987 to provide a forum and a collective voice for women in senior administrative ranks in Canadian universities, colleges and technical institutes. The primary purpose of SWAAC is the promotion of female leadership in Canadian universities, colleges and technical institutes

Eligibility: Women registered in Master's or PhD programs at any Member Institution of Universities Canada within a designated region are eligible to be nominated. Regions and number of awards are defined as follows, and eligibility shall rotate among them; Ontario - 5 awards; Western Provinces 4 awards; Quebec - 4 awards; Atlantic Provinces - 4 awards Level of Study: Graduate

Type: Award

Value: $\$ 3,000$

Frequency: Annual

Country of Study: Any country

Closing Date: 3 December

Funding: International office

\section{For further information contact:}

Email: natasha.mills@ryerson.ca 


\section{Social Sciences and Humanities Research Council Impact Awards}

Purpose: SSHRC Impact Awards are designed to build on and sustain Canada's research-based knowledge culture in all research areas of the social sciences and humanities. The awards recognize outstanding researchers and celebrate their research achievements, research training, knowledge mobilization, and outreach activities funded partially or entirely by SSHRC

Eligibility: 1 . Be a citizen or permanent resident of Canada at the time of nomination. 2. Be an active social sciences and humanities researcher or student. 3. Hold or have held SSHRC funding pertinent to the award category. 4. Be in good standing with SSHRC. 5. Be affiliated with an eligible institution

Level of Study: Graduate

Type: Award

Value: $\$ 100,000$

Frequency: Annual

Country of Study: Any country

Application Procedure: 1. Challenge - ambition and importance $(25 \%)$ : originality and significance of the body of work within the nominee's fields of research. 2. Achievementsimpact and outcomes (75\%): originality and significance of nominee's body of academic achievement and research, including quality of publications relative to stage of career; evidence of impact of the nominee's work within their fields of research and/or beyond the social sciences and humanities research community; nominee's ability and commitment to communicate research results within and/or beyond the academic community; level of nominee's engagement with, and quality of training and mentoring provided to, students, emerging scholars and participants, relative to the nominee's career level; and nominee's demonstrated potential for leadership and societal contributions within and/or beyond the academic community

Closing Date: 25 February

Funding: Private

\section{For further information contact:}

Research Training Portfolio, Social Sciences and Humanities Research Council, 350 Albert Street, P.O. Box 1610, Ottawa, ON K1P 6G4, Canada

Email: impactawards-priximpacts@sshrc-crsh.gc.ca

\section{The Dennis Mock Graduate Scholarship}

Purpose: The Dennis Mock Graduate Scholarship is available annually to recognize the accomplishments of a first-year
Master's student. This award was established in the name of Dennis Mock to honour his commitment to higher education, to recognize his leadership and dedication demonstrated during his 28 years at Ryerson, and to acknowledge his role in developing graduate studies at the university, as vicepresident, academic. The funds have been provided by the Peter Bronfman Scholarship Program and the Ontario Student Opportunities Trust Fund

Eligibility: 1. Completion of an undergraduate degree program at Ryerson. 2. Full-time enrollment in the first year of a Master's program at Ryerson, with a course load of at least two graded, one-term courses in the fall term. 3. First time enrollment in a graduate program. 4. Canadian Citizen or Permanent Resident. 5. Must meet the Ontario Residency Requirement (see Application form for details). 6. Demonstrated financial need

Level of Study: Graduate

Type: Scholarship

Value: $\$ 5,000$

Frequency: Annual

Country of Study: Any country

Closing Date: 18 March

Funding: Foundation

\section{For further information contact:}

Email: g2guerci@ryerson.ca

\section{The Dennis Mock Student Leadership Award}

Purpose: The Dennis Mock Student Leadership Awards recognize graduating students who have made outstanding voluntary extracurricular contributions to their school or academic program department, their faculty, or to Ryerson University as a whole. The awards acknowledge and encourage student participation in university affairs

Eligibility: 1. Students who graduated in Fall or will be graduating in Spring. 2. In a full-time or part-time Ryerson degree program. 3. Clear academic standing at the time of nomination

Level of Study: Graduate

Type: Award

Frequency: Annual

Country of Study: Any country

Closing Date: 19 February

Funding: International office

\section{For further information contact:}

Email: grdadmit@ryerson.ca 


\section{The Geoffrey F. Bruce Fellowship in Canadian Freshwater Policy}

Purpose: Geoffrey F. Bruce was a distinguished Canadian, dedicated public servant and diplomat who devoted his career to advancing multilateral cooperation in pursuit of environmental protection and sustainable development practices. Geoffrey was passionate about the stewardship of Canadian water resources

Level of Study: Graduate

Type: Fellowship

Value: $\$ 25,000$

Length of Study: 2 year

Frequency: Annual

Country of Study: Any country

Closing Date: 30 September, each year

Funding: Foundation

\section{For further information contact:}

Dr. Carolyn Johns, Chair, Geoffrey F. Bruce Fellowship, Selection Committee, Ryerson University, 350 Victoria Street, Toronto, ON M5B 2K3, Canada

Email: cjohns@ryerson.ca

\section{The Hydro One Aboriginal Award for Graduate Studies in Public Policy and Administration}

Purpose: The Hydro One Aboriginal Award for Graduate Studies in Public Policy and Administration provides financial assistance and recognizes the academic achievement of an Aboriginal student entering the Master of Arts in Public Policy and Administration program at Ryerson University. It is awarded to up to two Aboriginal students entering the program. Funds are provided Hydro One Networks Inc. and the Ontario Trust for Student Support (OTSS)

Eligibility: 1. A four year degree with a least a B+ average in the last two years of study. 2. Demonstrated competence in the English Language. 3. Canadian citizenship or be a protected person. 4. Ontario residency (in accordance with OTSS requirements). 5. Demonstrated financial need as determined by Ryerson University

Level of Study: Graduate

Type: Award

Value: Up to $\$ 10,000$

Frequency: Annual

Country of Study: Any country

Funding: International office
For further information contact:

Email: grdadmit@ryerson.ca

\section{The Pierre Elliott Trudeau Foundation Scholarship}

Purpose: The award supports interdisciplinary research and original fieldwork by providing a substantial yearly allowance for research and travel, enabling the Scholars to gain first-hand contact with the diverse communities that can enrich their studies. Moreover, each Scholar is paired with a distinguished Trudeau Mentor selected by the Foundation among the most eminent Canadian practitioners in all sectors of public life. The Scholarship also offers the opportunity to interact with an exceptional community of leaders and committed individuals in every field of the social sciences and humanities, to participate in events organized by the Foundation and to hold their own workshops, through available financial support

Eligibility: Be a Canadian citizen or landed immigrant applying to a doctoral program in the social sciences and humanities or registered full-time in the first or second year of such a program at a Canadian university

Level of Study: Graduate

Type: Scholarship

Value: $\$ 60,000$

Length of Study: 3 year

Frequency: Annual

Country of Study: Any country

Closing Date: 8 January

Funding: International office

\section{For further information contact:}

Natasha Mills, Scholarships Liaison Officer, Yeates School of Graduate Studies, Ryerson University, Toronto, ON, Canada

Tel: (1) 4169795000 ext. 3648

Email: natasha.mills@ryerson.ca

\section{The W. L. Mackenzie King Scholarships}

Purpose: The Mackenzie King Scholarships were established as an independent trust under the will of the late Rt. Hon. William Mackenzie King (1874-1950). Two classes of Mackenzie King Scholarship are available to graduates of Canadian universities: the Open Scholarship and the Travelling Scholarship. Both are to support graduate study

Eligibility: 1. The Mackenzie King Open Scholarship is open to graduates of any Canadian university who engage in (commence or continue) graduate study (mater's or doctoral) in any field, in Canada or elsewhere. One Open Scholarship is 
awarded annually. Its value has lately been $\$ 8,500$ but is subject to change. 2. The Mackenzie King Travelling Scholarship is open to graduates of any Canadian university who engage in (commence or continue) postgraduate study (mater's or doctoral) in the United States or the United Kingdom, of international relations or industrial relations (including the international or industrial relations aspects of law, history, politics and economics)

Level of Study: Graduate

Type: Scholarship
Value: $\$ 10,500$

Frequency: Annual

Country of Study: Any country

Closing Date: 1 February

Funding: International office

For further information contact:

Email: natasha.mills@ryerson.ca 